\title{
THE BIOMASS OF THE BOTTOM FAUNA IN THE ENGLISH CHANNEL OFF PLYMOUTH
}

\author{
By N. A. Holme \\ The Plymouth Laboratory
}

(Text-figs. I-7)

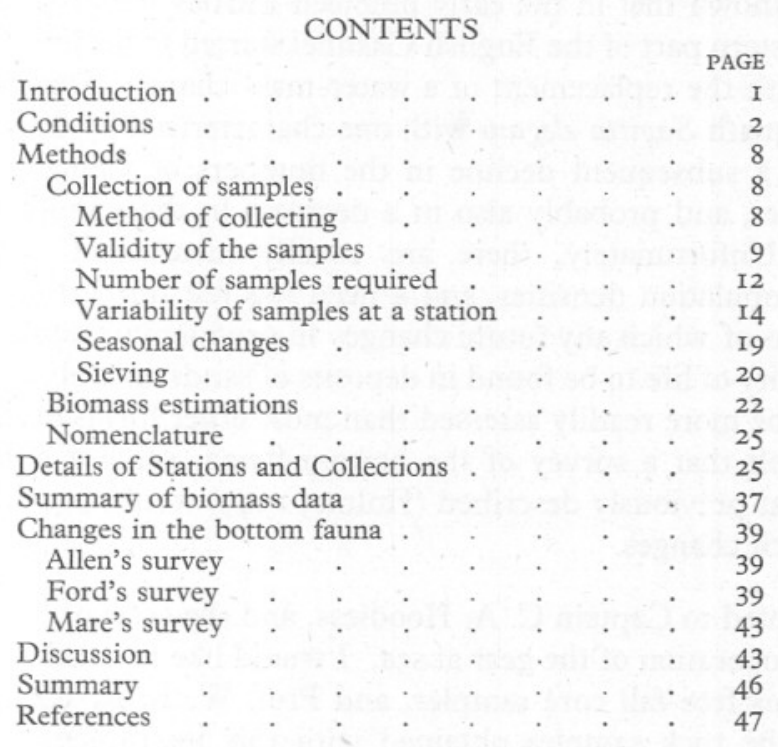

\section{INTRODUCTION}

The earliest survey of the bottom fauna in the English Channel off Plymouth is that of Allen (I899), who made a large number of dredge hauls in the neighbourhood of the Eddystone. His sampling was necessarily qualitative, and not until a quarter of a century later were any quantitative studies undertaken (Ford, 1923). Following the work of C. G. J. Petersen and others in Denmark, Ford made a survey of the communities near Plymouth, which he found to be Venus communities of two types, the occurrence of each type depending upon the grade of deposit.

Many workers have criticized the use of the Petersen grab as a quantitative instrument in deposits other than soft mud. It clearly does not dig deeply enough to sample all the fauna, but it has given valuable results for comparative purposes. 
Further quantitative work at Plymouth has been undertaken for more limited areas by Steven (1930) and by Smith (1932), using the Petersen grab and conical dredge respectively. Mare (1942) made a detailed study of the inhabitants of a muddy ground a few miles offshore, with particular reference to the micro-organisms. She gives the only available data on the quantity of living tissue per unit area of the sea-bed at Plymouth.

Elsewhere in the British Isles, Davis (1923, 1925) and Stephen (1923) have studied benthic communities in the North Sea, and more recently Jones (195I), in an account of the communities off the Isle of Man, has given figures for the quantity of living tissue per unit area.

It is well known that in the early nineteen-thirties the productivity of the sea in the western part of the English Channel started to decline. This change, associated with the replacement of a water-mass characterized by the planktonic chaetognath Sagitta elegans with one characterized by $S$. setosa, may be the cause of a subsequent decline in the numbers of young fish caught in a standard net, and probably also in a decrease in the populations of other organisms. Unfortunately, there are usually insufficient data to record changes in population densities, and a need was felt for further quantitative data by means of which any future changes in productivity could be followed.

The quantity of life to be found in deposits of sands, gravels or muds on the sea-bed can be more readily assessed than most other forms of life in the sea, and it was felt that a survey of the bottom fauna, using a bottom sampler similar to that previously described (Holme, 1949) would provide a basis for following such changes.

I am indebted to Captain C. A. Hoodless, and the crew of R.V. Sabella for their skill in operation of the gear at sea. I would like to thank Dr M. N. Hill for loan of his free-fall core sampler, and Prof. W. B. R. King, F.R.S., for identifying the rock samples obtained with this instrument. Mr F. A. J. Armstrong has given much assistance in suggesting methods for dry-weight determinations, and in other ways. The following have kindly identified or checked certain groups: Mr G. M. Spooner (Amphipoda), Miss P. Kott (Tunicata), Dr H. G. Vevers (Echinodermata), and Dr C. Burdon-Jones (Enteropneusta).

\section{CondiTions}

The area sampled is situated in the English Channel within 16 miles of Plymouth, and lies between $50^{\circ} 6^{\prime} \mathrm{N}$. and $50^{\circ} 20^{\prime} \mathrm{N}$., and between $4^{\circ} 5^{\prime} \mathrm{W}$. and $4^{\circ} 16^{\prime} \mathrm{W}$. The coastline between Lizard Point in Cornwall and Bolt Head in Devonshire sweeps northward to form a large open bay, thus providing slight protection from Atlantic swell, particularly in the western part of the bay, around Falmouth. Off the Eddystone, however, protection is negligible, but tidal streams in the bay are somewhat weaker than in the main part of the Channel to the southward. 
Depth. A mile or two off the coast near Plymouth the bottom shelves away steeply from 20 to $40 \mathrm{~m}$., and then slopes down very gently so that in midchannel, 60 miles to the south, the depth is only $100 \mathrm{~m}$. Except for three stations near shore, the area covered in this survey is on this gently sloping bottom, in depths of $40-70 \mathrm{~m}$. Twenty stations were worked in the survey; they were placed at 2-mile intervals along three lines running southward from the shore (Fig. I).

Tidal streams. Tidal streams near shore are variable in direction and strength, but out by the Eddystone they set east and west, reaching a velocity of over I knot (I829 m./hr.) at spring tides.

Wave action. It is difficult to assess the effects of wave action on the burrowing fauna. Atlantic swell and waves generated in the Channel must cause considerable disturbance in shallow water-in Whitsand Bay, for example, where large lamellibranchs such as Ensis are often washed in alive during storms. In deeper water the effects of wave action must be much reduced. Allen (1899) considered that the abundance of hydroids and the polyzoan Cellaria, which root themselves in the sand, was evidence that the grounds in the neighbourhood of the Eddystone were not subjected to violent disturbances at any time. In the immediate vicinity of the Eddystone reef, however, there is evidence of considerable wave action and tidal scour (Allen, I899, p. 376; Smith, I932, p. 253).

Deposits. The texture of the deposits is very variable and at certain stations inside the Eddystone a small change in position due to the ship drifting between one haul of the bottom-sampler and the next often results in a marked change in the nature of the sediment brought up (e.g. at stations $\mathrm{A}_{3}$ and $\mathrm{A}_{4}$ ). Samples of deposit, as brought up in the bottom-sampler, have been mechanically graded. The Wentworth grade scale has been adopted, and the soils have been graded through gauze sieves of the following apertures: $2, \mathrm{I}, \frac{1}{2}, \frac{1}{4}$, $\frac{1}{5}$ and $\frac{1}{8} \mathrm{~mm}$. A separation of particles over and under $\frac{1}{32} \mathrm{~mm}$. was made by sedimentation and repeated decantations. (The method is not described here in detail: further work involving mechanical analysis of soils in relation to their lamellibranch faunas is in progress, and a detailed account will be published with this work.)

The results of mechanical analysis are given in Table I, and cumulative curves for some stations are shown in Fig. 2.

Close inshore, in Whitsand Bay, a fairly clean sand is found; farther offshore this gives way to a patchwork of grounds extending out as far as the Eddystone. Off Whitsand Bay is the 'Rame mud' which is in fact largely composed of fine sand $\left(60 \%\right.$ between $\frac{1}{8}$ and $\frac{1}{32} \mathrm{~mm}$. grade at A2). Farther out the deposits range from coarse muddy sand to fine gravel mixtures: these two types are found both at $\mathrm{A}_{3}$ and $\mathrm{A}_{4}$. Where tidal scour is strong, there may occur patches of gravel, often largely composed of shell-remains and so forming a 'shell-gravel'. A typical shell-gravel occurs close to the Eddystone 


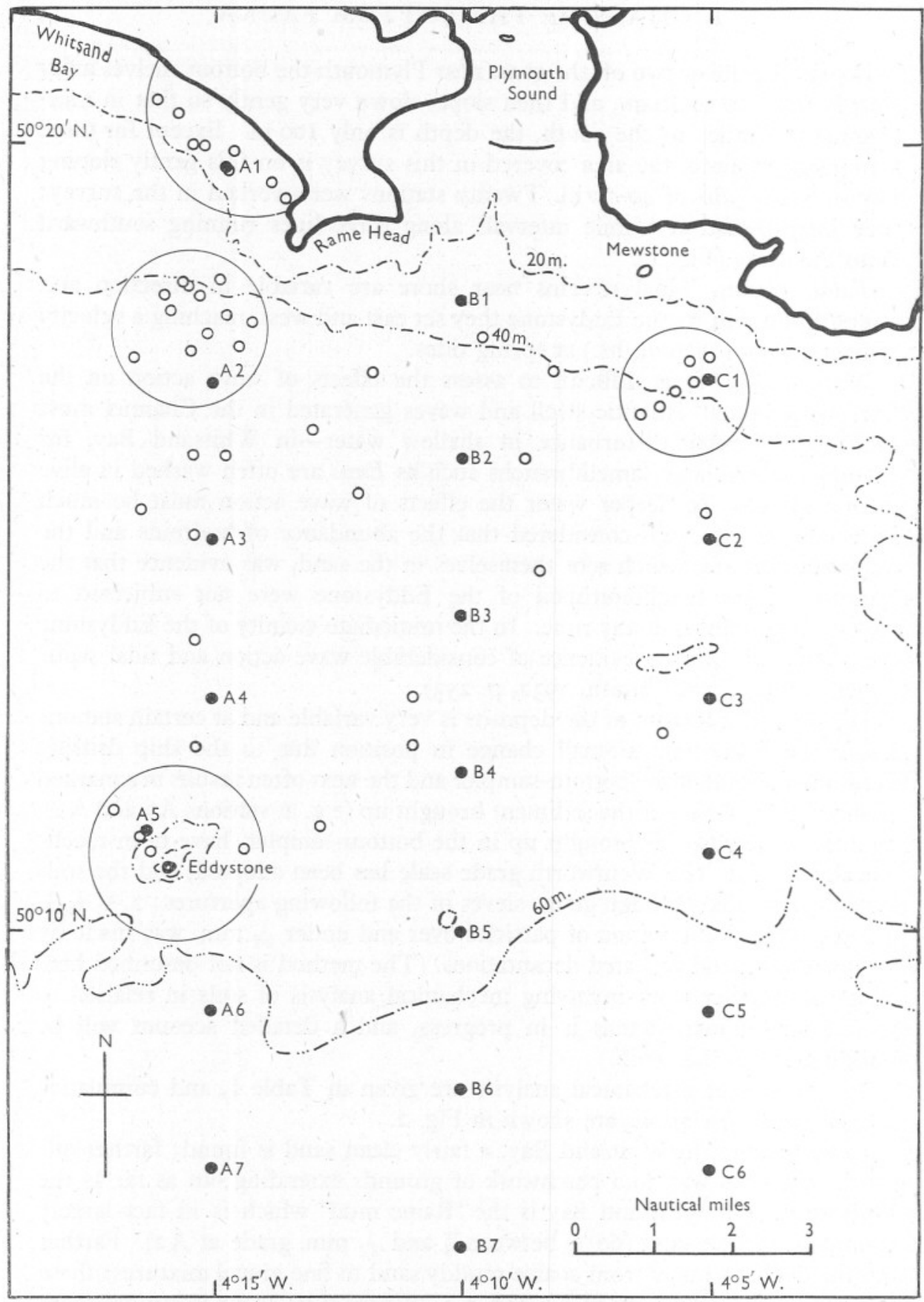

Fig. I. Chart of the English Channel off Plymouth. Depth contours in metres. I950 stations; O, Ford's stations; the four areas where samples have been grouped together (see p. 40) are enclosed in circles. 
(A 5), and there are other patches off Plymouth Sound (BI) and off the Mewstone (CI). In such places there are probably outcrops of bare rock in pockets of which the shell gravel rests. To the south and east of the Eddystone lies a fairly clean fine sand, its composition varying little from station to station (A 6, 7, B4, 5, 6, 7, C4, 5, 6.)

Nowhere was the soil below the surface found to be black from the presence of ferrous sulphide, and the soils therefore may be assumed to be well

\section{Table I. Soll Grades, Expressed as Percentages by Weight}

(Figures in brackets after station numbers indicate the serial number of the haul.)

\begin{tabular}{|c|c|c|c|c|c|c|c|c|}
\hline \multirow[b]{2}{*}{ Station } & \multicolumn{8}{|c|}{ Grade (mm.) } \\
\hline & $>2$ & $2-I \cdot O$ & $\begin{array}{l}1.0- \\
0.5\end{array}$ & $\begin{array}{l}0.5- \\
0.25\end{array}$ & $\begin{array}{l}0.25- \\
0.20\end{array}$ & $\begin{array}{l}0.20- \\
0.125\end{array}$ & $\begin{array}{l}0.125- \\
0.0313\end{array}$ & $<0.0313$ \\
\hline $\mathrm{A}_{\mathrm{I}}$ & 0.07 & 0.37 & $I \cdot I I$ & 6.09 & 8.62 & $63 \cdot 74$ & $19 \cdot 76$ & 0.22 \\
\hline $\mathrm{A} 2$ & 0.13 & $I \cdot 29$ & $\mathrm{I} \cdot 87$ & 4.06 & $I \cdot 67$ & II I I & $60 \cdot 27$ & 19.58 \\
\hline $\mathrm{A}_{3}(\mathrm{I}-2)$ & $0.7 \mathrm{I}$ & $I \cdot 20$ & 10.35 & $26 \cdot 54$ & $5 \cdot 49$ & 35.95 & I $8 \cdot 24$ & $I \cdot 52$ \\
\hline$A_{3}(3-4)$ & $28 \cdot 90$ & $\mathrm{I} 4 \cdot \mathrm{I} 8$ & $9.8 \mathrm{I}$ & $9 \cdot 00$ & $I \cdot 62$ & I2.3I & $17 \cdot 15$ & $7 \cdot 03$ \\
\hline $\mathrm{A}_{4}$ (I) & $I \cdot 20$ & $2 \cdot 99$ & $9 \cdot 56$ & 30.57 & $7 \cdot 77$ & $25 \cdot 96$ & I9.04 & 2.90 \\
\hline $\mathrm{A}_{4}(2)$ & $27 \cdot 73$ & $10 \cdot 86$ & $7 \cdot 73$ & 13.73 & 3.29 & 13.29 & 17.69 & 5.69 \\
\hline A 5 & $49 \cdot 16$ & $38 \cdot 04$ & $9 \cdot 36$ & 2.03 & 0.18 & 0.35 & 0.52 & 0.35 \\
\hline A6 & 0 & 0.15 & $2 \cdot 37$ & I4.59 & $7 \cdot 70$ & $6 I \cdot 63$ & $12 \cdot 30$ & $I \cdot 26$ \\
\hline A 7 & 0.07 & 0.20 & $\mathrm{I} \cdot 92$ & I7.98 & $6 \cdot 37$ & 63.04 & $9 \cdot 36$ & $I \cdot 06$ \\
\hline B I & 48.03 & 32.05 & I6.5I & $\mathrm{I} \cdot 48$ & 0.09 & 0.35 & 0.87 & $0.6 \mathrm{I}$ \\
\hline $\mathrm{B} 2$ & 27.05 & 8.08 & 7.03. & $9 \cdot 22$ & $2 \cdot 07$ & I I $\cdot 48$ & $26 \cdot 46$ & $8 \cdot 60$ \\
\hline $\mathrm{B}_{3}$ & 0.32 & $I \cdot 60$ & $4 \cdot 87$ & $6 \cdot 85$ & I. 79 & 44.01 & $36 \cdot 19$ & $4 \cdot 36$ \\
\hline B 4 & 0.45 & 0.53 & 3.04 & $10 \cdot 22$ & 3.82 & $55 \cdot 87$ & 23.48 & $2 \cdot 59$ \\
\hline B 5 & 0.07 & 0.75 & 3.40 & $7 \cdot 34$ & I0.8I & $59 \cdot 28$ & I6.93 & I. 43 \\
\hline $\mathrm{B} 5^{\star}$ & 0.44 & 0.89 & $3 \cdot 34$ & $9 \cdot 39$ & $12 \cdot 54$ & $60 \cdot 01$ & 12.59 & 0.79 \\
\hline B 6 & 0.06 & $\mathrm{r} \cdot 07$ & $3 \cdot 74$ & II $\cdot 87$ & 6.53 & $62 \cdot 73$ & I3.00 & I.OI \\
\hline B 7 & 0 & 0.16 & $I \cdot 8 \mathrm{I}$ & I4.90 & $6 \cdot 74$ & 67.01 & 8.II & $I \cdot 26$ \\
\hline CI $(3-4)$ & I 4.45 & $4 \mathrm{I} \cdot 80$ & $37 \cdot 75$ & $4 \cdot 22$ & 0.25 & 0.29 & 0.63 & 0.63 \\
\hline $\mathrm{C}_{2}$ (3) & 6.93 & $8 \cdot 45$ & $7 \cdot 19$ & I $4: 32$ & $3 \cdot 10$ & $2 I \cdot 56$ & $32 \cdot 58$ & $5 \cdot 88$ \\
\hline $\mathrm{C}_{3}(2)$ & $2 \mathrm{I} \cdot 32$ & I6.73 & $4 \cdot 18$ & $2 \cdot 43$ & 0.47 & 6.95 & 36.03 & II $\cdot 88$ \\
\hline $\mathrm{C}_{4}$ & 0 & 0.15 & 0.66 & $2 \cdot 93$ & $4 \cdot 75$ & $69 \cdot 63$ & I9.76 & $2 \cdot I 2$ \\
\hline $\mathrm{C}_{4} \mathrm{t}$ & 0.07 & 0.82 & 0.67 & $I \cdot 80$ & $2 \cdot 10$ & $55 \cdot 17$ & $38 \cdot 38$ & 0.97 \\
\hline $\mathrm{C}_{5}$ & 0 & 0.05 & 0.31 & 6.55 & II $\cdot 27$ & $67 \cdot 35$ & $13 \cdot 26$ & $I \cdot 2 I$ \\
\hline C6 & 0 & 0.15 & 0.95 & II. 66 & $6 \cdot 82$ & $69 \cdot 94$ & 9.53 & 0.95 \\
\hline
\end{tabular}

oxygenated. I have found this the usual condition of soils in the English Channel. The only soil so far found to be black below the surface was in Torbay (p. II), where tidal streams are weak and stagnant conditions resulting from deposition of organic matter may arise from time to time.

The low percentage of silt $(<0.03 \mathrm{I} 3 \mathrm{~mm}$.) in the deposits outside the Eddystone suggests that there is little or no net deposition in the area. Thus benthic filter- and deposit-feeding organisms cannot be dependent on a continual rain of dead organisms, faecal pellets or other organic detritus from the overlying water, except possibly during calm weather and at neap tides when there is a minimum of disturbance near the bottom. Normally such detritus must stay in suspension to be fed on by filter-feeding planktonic and 
benthic organisms or by bacteria. These conclusions are supported by the work of Armstrong \& Harvey (1950), who found that water samples taken very close to the bottom had a phosphorus content only a little higher than that of the overlying water. From this it was inferred that there was no material deposit of detritus rich in phosphorus.

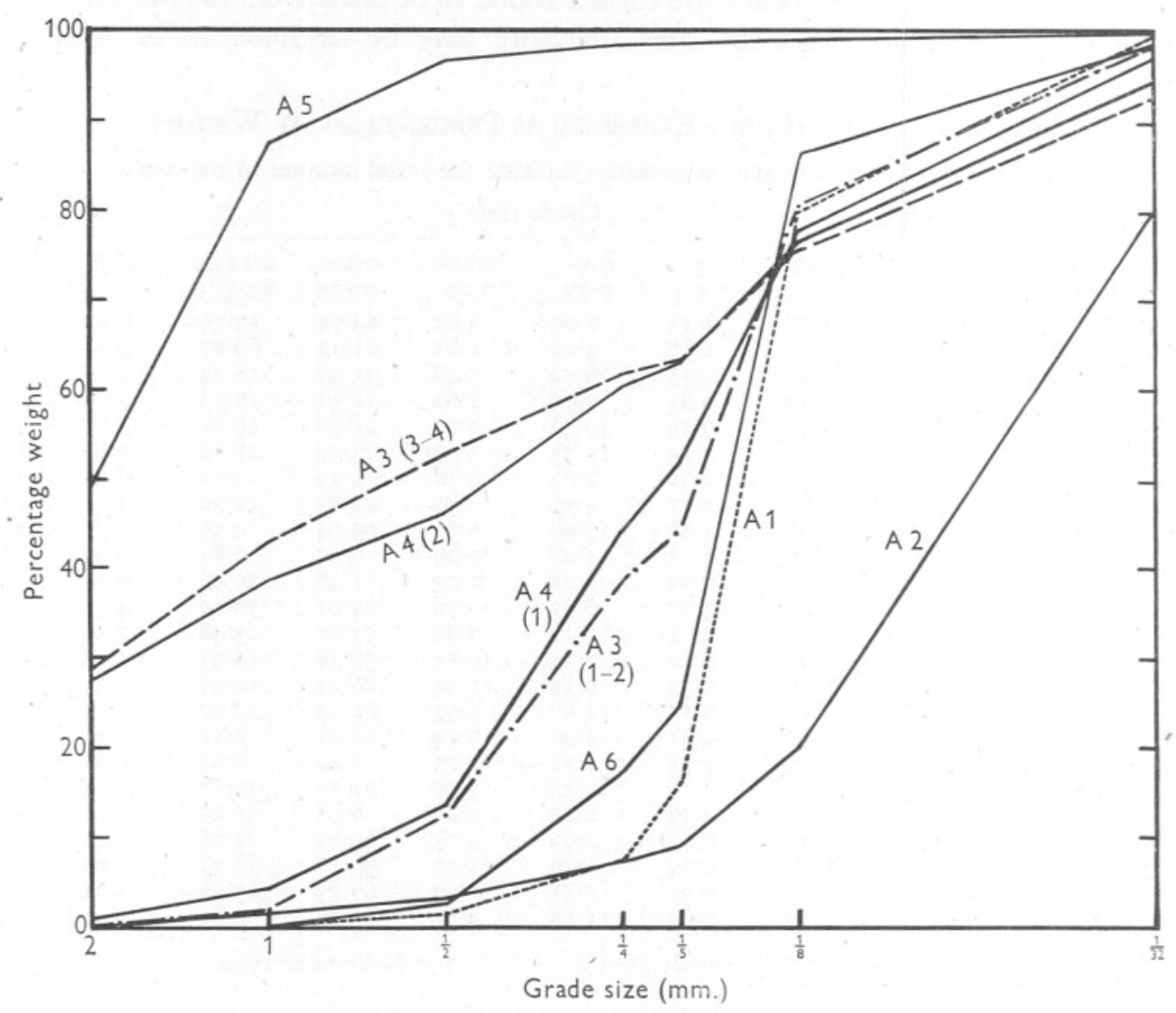

Fig. 2. Cumulative curves of the soil grades of stations on the 'A' line. Note the variation in soil grade in different hauls at $\mathrm{A}_{3}$ and $\mathrm{A}_{4}$. The soil at $\mathrm{A}_{7}$, which is not included, is similar to that at A6.

Depth of sediment. Until lately, nothing was known of the depth of sediment overlying the solid rock forming the floor of the English Channel. Recent work by King (1950) and by M. N. Hill, using a modified Stetson free-fall corer, has shown that there is only a thin veneer of sediment in many places in the western half of the Channel.

Core-samples have been taken at seventeen of the twenty stations worked in the benthos survey, and rock has been found at eleven of these (Table II). When the coring tube strikes rock it often penetrates a short distance, the 
rock breaking off and forming a plug in the jaws of the tube. In this way a core of the overlying sediment may be obtained. If the coring tube fails to enter rock a core of sand is often retained by an arrangement of flap-valves near the mouth of the tube. The depth of the sediment has been calculated from the volume of the sample. Where no rock was taken this represents the minimum depth of sediment. Possibly some of the depths recorded at stations where no rock was taken represent the total depth of sediment, the corer not having sufficient momentum after passing through $30 \mathrm{~cm}$. or more of sand to penetrate the rock.

\section{Table II. Depth of Sediment and Geological Nature OF THE UNDERLYING ROCK}

\begin{tabular}{|c|c|c|}
\hline & $\begin{array}{l}\text { Depth of } \\
\text { sediment } \\
\text { (cm.) }\end{array}$ & Rock \\
\hline A I $a^{\star}$ & c. I & Devonian slates \\
\hline$b^{\star}$ & I8.0 & Devonian slates \\
\hline $\mathrm{A}_{2}$ & $10 \cdot 4$ & Red rubble, probably N.R.S. \\
\hline $\mathrm{A}_{3}$ & $>7 I \cdot 5$ & . \\
\hline $\begin{array}{l}\text { A } 4 \\
\text { A } 6\end{array}$ & $\begin{aligned} & 33 \cdot 8 \\
& 2 \mathrm{I} \cdot 8\end{aligned}$ & $\begin{array}{l}\text { Red rubble breccia with limestone fragments. } \\
\text { Almost certainly N.R.S. }\end{array}$ \\
\hline $\mathrm{A}_{7}$ & $32 \cdot 2$ & Fine red rather marly N.R.S. \\
\hline $\mathrm{B}_{3}$ & I9.4 & $\begin{array}{l}\text { Breccia, mainly small slate fragments. Almost } \\
\text { certainly N.R.S. }\end{array}$ \\
\hline $\begin{array}{l}\mathrm{B}_{3} / 4 \dagger \\
\mathrm{B}_{4} \\
\mathrm{~B} 5\end{array}$ & $\begin{aligned} &>c . 50 \\
& 36 \cdot 0 \\
& 33 \cdot 3\end{aligned}$ & $\begin{array}{l}\text { Breccia of quartzite fragments. N.R.S. } \\
\text { Firm fine N.R.S. }\end{array}$ \\
\hline $\begin{array}{l}\text { B } 6 \\
\text { B } 7 \ddagger\end{array}$ & $\begin{array}{r}>25 \cdot 0 \\
2 \mathrm{I} \cdot 7\end{array}$ & Fairly coarse N.R.S. \\
\hline $\begin{array}{l}\mathrm{C}_{1} \\
\mathrm{C}_{2} \\
\mathrm{C}_{3}\end{array}$ & $\begin{array}{l}\text { I } 9 \cdot 4 \\
3 \mathrm{I} \cdot 4 \\
\mathrm{O}\end{array}$ & $\begin{array}{l}\text { Fine, typical, N.R.S. } \\
\text { Very fine loamy N.R.S. } \\
\text { Mica schist }\end{array}$ \\
\hline$C^{\circ}$ & $>33 \cdot 3$ & . \\
\hline 5 & $>38.9$ & . \\
\hline & $>27 \cdot 8$ & 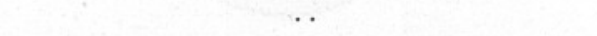 \\
\hline
\end{tabular}

* Sample $a$ from roo yards west of the wreck in Whitsand Bay, sample $b$ from roo yards north-west of the wreck.

$\dagger$ Mid-way between $\mathrm{B}_{3}$ and $\mathrm{B}_{4}$.

Three previous drops had failed to take a rock sample.

N.R.S., New Red Sandstone.

Estimated depths of sediment are shown in Table II. At $\mathrm{C}_{3}$ rock is exposed at the surface, and at A I the sediment was only I cm. deep in one haul. At the other stations where rock was taken the minimum depth was I0.4 cm., and the mean $25.0 \mathrm{~cm}$. Although most of the burrowing fauna is believed to be present in the top Io or $20 \mathrm{~cm}$. of soil, it is evident that the shallowness of the soil may often restrict the occurrence or growth of deeper burrowing species, some of which are thought to penetrate at least $30 \mathrm{~cm}$. into the sediment. 


\section{METHODS \\ Method of collecting \\ Collection of samples}

Samples were taken with a modified form of 'scoop-sampler', as already described (Holme, I949), but having two counter-rotating scoops instead of the single one (Fig. 3 ). $54 \mathrm{~kg}$. of weights were added to the frame, bringing the total weight to about II $5 \mathrm{~kg}$. It was hoped that the use of two scoops would

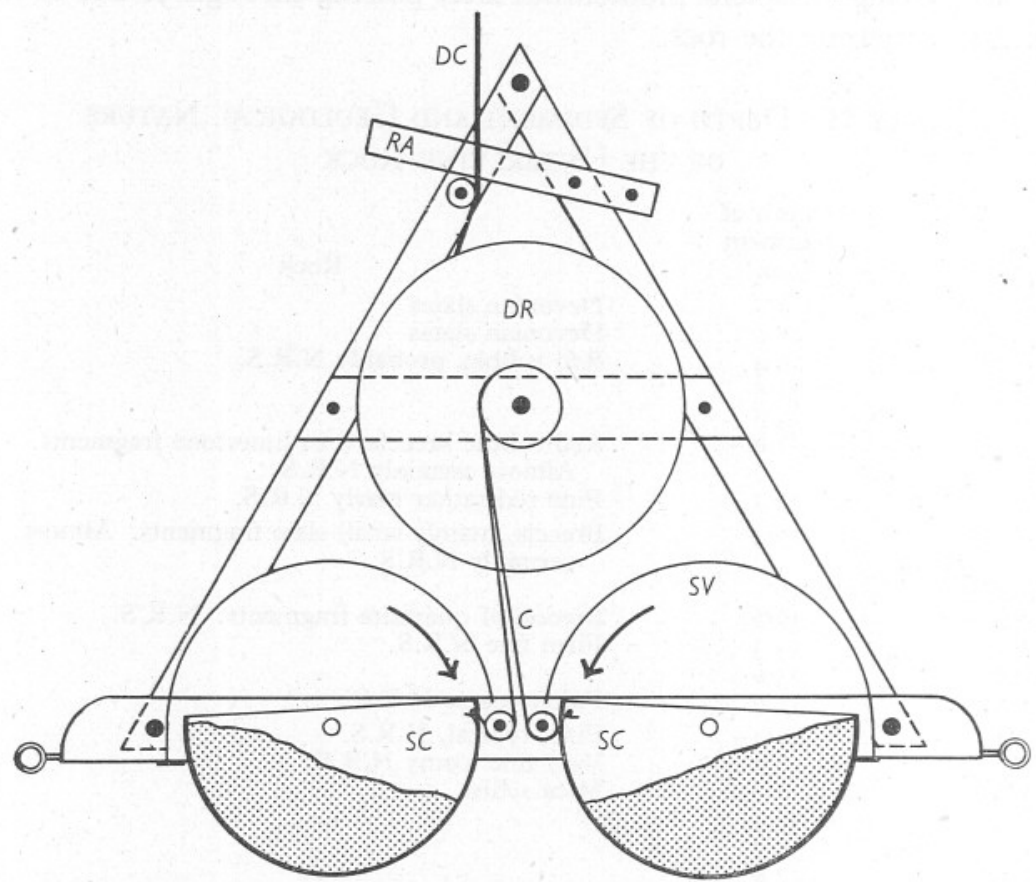

Fig. 3. Diagram of the double-scoop sampler (cf. Holme, 1949, Figs. I and 2). The scoops are in the closed position. $C$, small cables which pull the scoops round; $D C$, the main cable which has unwound from the drum and by which the sampler is hoisted; $D R$, drum; $R A$, release arm; $S C$, scoops; $S V$, scoop-covers. The soil sample is stippled.

eliminate the lateral movement of the frame during digging, and so produce a larger sample. Samples taken with the new instrument were, however, not larger than with the previous instrument, but twice the area is sampled at each haul. In addition, the faunas taken by the two scoops can be compared, to give data on the degree of patchiness of the bottom-fauna.

Each scoop samples a rectangular area which in vertical section is nearly semicircular, like half a cheese. If the scoop is digging to its fullest extent an area $36 \times 15.3 \mathrm{~cm}$. is sampled, which is equal to $0.055 \mathrm{~m} .^{2}$, in practice the - scoops do not usually dig to the maximum depth of $15 \mathrm{~cm}$., and a correspondingly smaller surface area is covered. In addition, the area sampled 
decreases with depth in the sediment. For practical purposes each scoop is assumed to sample $0.05 \mathrm{~m} .^{2}$.

No doubt the scoops would dig more deeply in the firmer sediments if the frame were more heavily weighted, but the weight of the apparatus is limited by the size of the ship and the facilities available for handling it on board.

Five hauls were made with the sampler at each station, covering a total area of $0.5 \mathrm{~m} .{ }^{2}$. The ship was allowed to drift while the hauls were being taken, but as sampling was always carried out in fine weather the amount of drift was not great. Once or twice a marker float was anchored at the original position, and the ship was found to drift not more than $\frac{1}{4}-\frac{1}{2}$ mile during the 20-30 min. necessary to take the five samples (see p. I4 and p. 29, station B2).

On grounds within a few miles of the shore it is possible to drift over a variety of types of bottom-soil while sampling at a station. On these grounds the soils are sometimes so patchy that a drift of only a few yards may result in a complete change in the nature of the sample brought up (see also Ford, I923, p. I67). On such grounds the fauna listed for any one station may therefore represent samples from the different 'communities' characterizing the various grades of bottom soils. For the purpose in hand, of assessing the total quantity of life on the sea-bed, this is no great disadvantage, but it would be unwise to attempt to correlate the distribution of species at these stations with the soil grades as shown in Table I. Under such conditions each haul would have to be treated as a separate sample.

On grounds farther offshore, the drift of the ship while on station has no appreciable effect on the fauna brought up (see p. 30).

\section{Validity of the samples}

The volume of soil brought up by the sampler is some indication of the depth to which it is digging, but since there is little information on the vertical distribution of species in the soil its efficiency can only be judged against that of other instruments.

It is well known that on soils other than mud the $\mathrm{I} / \mathrm{IO} \mathrm{m}^{2}$ Petersen grab does not dig deep enough to sample all the fauna. Johansen (I927) gives an interesting comparison between the performances of the Petersen grab and the Knudsen sampler, which can dig to a depth of $30 \mathrm{~cm}$. in sand. It has already been shown (Holme, I949) that the 'scoop-sampler' samples sandy grounds more efficiently than does the Petersen grab, and a further comparison is given in Table III.

From observations on intertidal banks it is known that the majority of individuals are to be found in the top $15 \mathrm{~cm}$. or so, and Johansen (I927), working with the Knudsen sampler in shallow water, considers that 'invertebrates are not taken beyond about $12-25 \mathrm{~cm}$. down in the sea floor'.

A brief survey by Molander (I928) of the vertical distribution of the fauna in Gullmar Fjord, using a square coring instrument with an occluding 
shutter, indicates that the majority of species and individuals are to be found in the top $5 \mathrm{~cm}$. of the sediment, few occurring below $10 \mathrm{~cm}$. The maximum depth of sampling was only $15 \mathrm{~cm}$., however, so some deep-living species may have been missed.

In general it is probably safe to assume that most individuals occur in the top I $5 \mathrm{~cm}$., but the few living below this depth are mostly rather large forms and sometimes must contribute largely to the total weight of animal tissue per unit area.

Undoubtedly the 'scoop-sampler', which digs to a maximum of $15 \mathrm{~cm}$., misses deep burrowing forms, such as Upogebia and Callianassa-which are probably much more numerous than the figures given in this paper suggest. For some species, however, the effective sampling depth is greater than I5 cm., as with large lamellibranchs (particularly Lutraria) whose siphons are from time to time taken in the scoop. These animals live perhaps $30 \mathrm{~cm}$. down in the sediment and are seldom taken, but from the size of the severed siphon the size of the whole animal can be estimated.

It is uncertain to what extent active surface-living forms can evade the sampler. Small fish, prawns, etc., can probably dart out of the way as the sampler descends, but it seems unlikely that crabs or scallops (Pecten, Chlamys) can move fast enough to escape. Once the sampler reaches the seabed its construction makes it difficult for them to escape.

There is a small loss of soil and possibly of animals as the sampler reaches the surface and the water in the scoop-cover empties out around the scoop; and once on board the water with contained animals may slop on the deck, particularly if there is any swell at the time. These losses, however, are considered to have been small.

While testing a new 'suction'-coring apparatus (Fig. 4), a comparison was made between the number of individuals taken against those taken at the same place with the $\frac{1}{20} \mathrm{~m} .{ }^{2}$ single-scoop sampler and a $\frac{1}{10} \mathrm{~m} .{ }^{2}$ Petersen grab. Although the suction-corer is not in general use, mainly because it is rather difficult to handle on board ship, a brief description is included here.

The corer consists of coring-tube $(C) 36 \mathrm{~cm}$. long and of $16.25 \mathrm{~cm}$. internal diameter, the top of which is in communication with an air chamber $(P)$. This assembly is supported by a pipe frame, which rests on the sea-bed and through which the assembly slides into the sediment. It is lowered from the stationary ship, and when it strikes the bottom the tap $(T)$ is opened, to give a negative pressure in the coring tube as water rushes in to compress the air in the chamber. It takes about $30 \mathrm{sec}$. for all the water to enter the chamber, and during this time the coring tube is sinking into the sediment, aided by the reduced pressure inside the tube. The release $(R)$ at the top of the chamber has disconnected from the main warp when the cable slackened so that, on hauling up, a lifting force is transmitted to the lifting arms $(L A)$, which are nearly horizontal at this stage. As the coring tube is pulled out of the sediment the whole sampler turns over and finally swings under its own weight to bring the open end of the coring tube uppermost. The sample is retained in the coring tube by the sheet of 
gauze $(G)$, but the open end of the tube is not covered. As the sampler comes up, the air in the chamber expands under the reduced pressure. The tap $(T)$ has previously closed as the instrument was inverted, and the air is blown off to the exterior through a small valve.

The suction produced was found to increase penetration into the sediment, but penetration would probably have been greatly improved if the coring assembly had been more heavily weighted. The volume of the sample is very little less than would be expected from the measured depth of penetration, there being apparently little loss while the sampler is turning over.

The sampler resembles that of Knudsen (1927), except that suction is produced by hydrostatic pressure instead of by a pump, and that there is a frame supporting the instrument on the bottom.

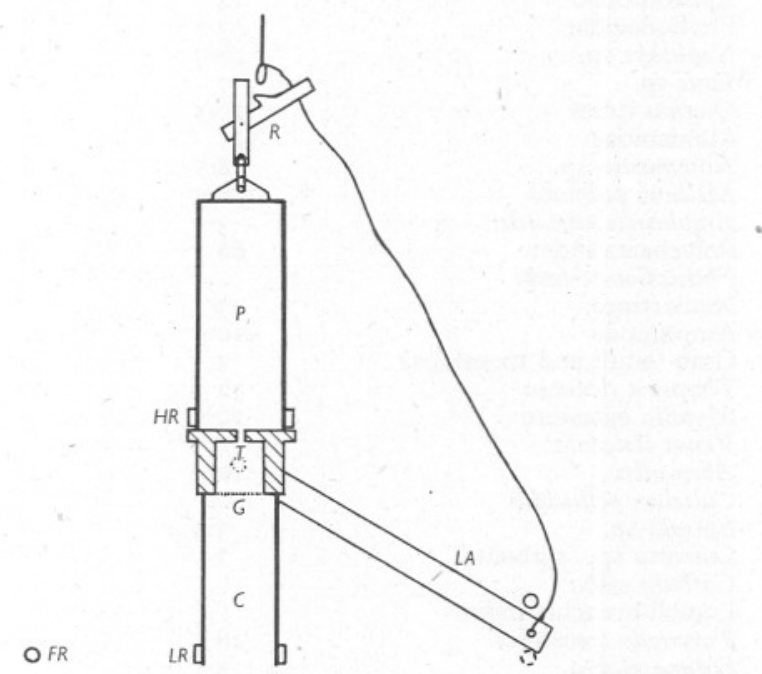

Fig. 4. Diagram of the suction-corer in vertical section. Many details have been omitted. $C$, coring tube; $F R$, pipe frame, which rests on the sea bed, and which is connected to the upper $(H R)$ and lower $(L R)$ metal rings through which the coring assembly slides. $G$, gauze covering top of coring tube; $L A$, lifting arms, the position of the bolts on which these rotate is dotted. The pipe frame has an upward U-bend to make room for the end of the lifting arms. $P$, pressure chamber; $R$, release; $T$, position of tap mechanism.

The sample taken by this or any other coring tube is more satisfactory in that the cross-sectional area is uniform at all depths in the sample, whereas in the scoop-sampler it decreases with depth.

Details of the comparative hauls are given below:

I6. xi. I949. Brixham Breakwater, light bearing $\mathrm{I} 45^{\circ} \mathrm{T}$., I $\cdot 25$ sea miles (middle of Torbay). Depth: $10.5 \mathrm{~m}$. (from chart).

R.V. Sabella anchored. Fine muddy sand, black below top $2-3 \mathrm{~cm}$. $1 \cdot 2 \mathrm{~mm}$. mesh sieve.

(i) Suction-corer $\left(\frac{1}{50} \mathrm{~m} .{ }^{2}\right)$, fourteen hauls, total area $0.28 \mathrm{~m} .{ }^{2}$. Length of cores (cm.): $20,14,13,29,20,15,7 \cdot 5,9,11 \cdot 5,16 \cdot 5,21 \cdot 5,21 \cdot 5,16 \cdot 5,18$ (the variation in length of the cores is partly due to experimental alteration in the rate and timing of the 'vacuum' release). Mean length: $16 \cdot 6 \mathrm{~cm}$. 
(ii) Petersen grab $\left(\frac{1}{10} \mathrm{~m}^{2}\right)$, five hauls, total area $0.5 \mathrm{~m} .{ }^{2}$. The mean volume of the sample corresponded to a 'bite' of about $3 \mathrm{~cm}$.

(iii) Single-scoop sampler $\left(\frac{1}{20} \mathrm{~m}^{2}\right)^{2}$, with $50 \mathrm{~kg}$. weights. Total area: $0.25 \mathrm{~m} .^{2}$. Samples about 31 . each, corresponding to a maximum penetration of $7-10 \mathrm{~cm}$., and a mean penetration of $6 \mathrm{~cm}$.

Table III. Comparison of Faunas taken by the $\frac{1}{50} M .^{2}$ Suction-Corer, $\frac{1}{10} M .^{2}$ Petersen Grab, AND the $\frac{1}{20} M .{ }^{2}$ SCOOP-Sampler. Densities Per $M .{ }^{2}$

\begin{tabular}{|c|c|c|c|c|}
\hline & & $\begin{array}{l}\text { Suction- } \\
\text { corer }\end{array}$ & $\begin{array}{c}\text { Petersen } \\
\text { grab }\end{array}$ & $\begin{array}{l}\text { Scoop- } \\
\text { sampler }\end{array}$ \\
\hline Anemones & & 7 & Io & 12 \\
\hline Aphroditidae & & I4 & $\cdots$ & $\cdots$ \\
\hline $\begin{array}{l}\text { Phyllodocidae } \\
\text { Nephthys } \mathrm{sp} \text {. }\end{array}$ & & 3.5 & $\ddot{2}$ & $\ddot{M}$ \\
\hline $\begin{array}{l}\text { Nephthys sp. } \\
\text { ? Eone sp. }\end{array}$ & & $28 \cdot 5$ & 24 & 44 \\
\hline $\begin{array}{l}\text { ?Eone sp. } \\
\text { Owenia tubes }\end{array}$ & & $\begin{array}{l}7 \\
10.5\end{array}$ & $\begin{array}{l}\cdots \\
\cdots\end{array}$ & i2 \\
\hline Maldanidae & & III & IO & 148 \\
\hline Notomastus sp. & & $28 \cdot 5$ & 2 & 32 \\
\hline Melinna palmata & & $278 \cdot 5$ & 62 & 268 \\
\hline & ' & 68 & $\ddot{6}$ & 4 \\
\hline $\begin{array}{l}\text { Polychaeta indet. } \\
\text { Phascolion strombi }\end{array}$ & & $\begin{array}{c}68 \\
\cdots\end{array}$ & $\begin{array}{l}6 \\
2\end{array}$ & $\begin{array}{l}96 \\
\ldots\end{array}$ \\
\hline Nemertinea & & 7 & 2 & . \\
\hline Amphipoda & & 10.5 & 12 & 24 \\
\hline Crab (adult and megalopa) & & 7 & $\ddot{\theta}$ & $\ldots$ \\
\hline Thyasira flexuosa & & 32 & I8 & 32 \\
\hline Mysella bidentata & - & 10.5 & 4 & .8 \\
\hline Venus striatula & & $\cdots$ & 2 & 8 \\
\hline Abra alba & & $10 \cdot 5$ & I2 & 8 \\
\hline Cultellus pellucidus & & $\ddot{2}$, & 2 & 4 \\
\hline $\begin{array}{l}\text { Spisula } \text { sp. } \\
\text { Lutraria sp. (siphons) }\end{array}$ & & 3.5 & 8 & $\because$ \\
\hline $\begin{array}{l}\text { Lutraria sp. (siphons) } \\
\text { Corbula gibba }\end{array}$ & & 7 & $\because$ & $\begin{array}{l}4 \\
4\end{array}$ \\
\hline $\begin{array}{l}\text { Corbula gibba } \\
\text { Lamellibranchia indet. }\end{array}$ & & $\cdots$ & $\ddot{\ldots}$ & $\begin{array}{l}4 \\
4\end{array}$ \\
\hline Turritella communis & & $28 \cdot 5$ & 26 & $40^{\circ}$ \\
\hline ?Eulima glabra & & 3.5 & . & 4 \\
\hline Cylichna sp. & & $\cdots$ & $\cdots$ & 4 \\
\hline Philine sp. & & 3.5 & 2 & $\cdots$ \\
\hline $\begin{array}{l}\text { Gastropoda indet. } \\
\text { Amphiura filiformis }\end{array}$ & & $\begin{array}{l}3.5 \\
193\end{array}$ & $\ddot{26}$ & $\ddot{2} \dot{6}$ \\
\hline Synapta & 18 & $3 \cdot 5$ & $\cdots$ & . \\
\hline Total & & 883.5 & 230 & 976 \\
\hline
\end{tabular}

A comparison of the faunas taken is given in Table III. The number of individuals taken by the suction-corer, which penetrated to about $17 \mathrm{~cm}$., is of the same order as that taken by the scoop-sampler, which had dug half as deeply. This indicates that the majority of species were aggregated in the top 7-IO cm.; Lutraria, however, of which only siphons were taken, was out of reach of both samplers. The Petersen grab, which was only digging to about $3 \mathrm{~cm}$. depth, was clearly not sampling the fauna adequately.

\section{Number of samples required}

Three series of observations have been made to find the number of hauls necessary for a qualitative evaluation of the fauna. Clearly the number of 
hauls required will vary with the objects of any investigation and local conditions. At each station the animals taken in each haul were kept separately and identified. At two stations the ship was anchored while the hauls were made; but at B 5 the ship was drifting over a ground of fairly even faunistic composition (see p. 19). A series of Ioo samples taken by Petersen and Boysen Jensen is included for comparison. These were taken with the $\frac{1}{10} \mathrm{~m} .{ }^{2}$ Petersen grab at various points in Thisted Bredning, the fauna being similar all over the Broad.

(i) Bigbury Bay. 20. iv. 49. Borough Island, bearing $023^{\circ} \mathrm{T}$, I.0 sea miles. Depth: $25.6 \mathrm{~m}$. (from chart). Muddy sand.

R.V. Sabella anchored. Fifteen hauls with the single-scoop sampler $\left(\frac{1}{20} \mathrm{~m} .{ }^{2}\right)$ $\mathrm{I} \cdot 2 \mathrm{~mm}$. sieve.

(ii) Whitsand Bay. 6. v. 49. Rame Head, bearing $\mathrm{I} 44^{\circ}$ T., $\mathrm{I} \cdot 83$ sea miles. Depth: c. $9 \mathrm{~m}$. (from chart). Sand with shale fragments. R.V. Sabella anchored. Fourteen hauls with the single-scoop sampler, then further anchor chain let out so that ship drifted back a little and a further six hauls made. I.2 mm. sieve.

(iii) Station B 5. 5. xii. 50 (see p. I4).

R.V. Sabella drifting. Twenty hauls made with the double-scoop sampler $\left(2 \times \frac{1}{20} \mathrm{~m} .{ }^{2}\right)$. Each scoop-full is considered separately.

(iv) Thisted Bredning. See Petersen \& Boysen Jensen (I9I I), Table I. $\frac{1}{10} \mathrm{~m}^{2}{ }^{2}$ grab.

The species found in each haul are shown in Tables IV-VI. Not all species have been identified: under 'unidentified Polychaeta' are usually lumped the less easily identifiable worms which are in any case often fragmented after collection, sieving and preserving. The total number of species recorded is therefore a minimum figure.

During identification there is a possibility of bias arising from the order in which the individual samples are examined. Where not every species is identified there is the choice of identifying a species or lumping it with the unidentified forms. Thus an unknown worm in the first haul examined might be identified down to its species, but if the first individual had been found in the last haul it might not have been identified. It is therefore important that the order of the samples be randomized before plotting the total number of species against the area sampled. The records from Whitsand Bay and Bigbury Bay were randomized after identification but before plotting the curves, but the samples from station $\mathrm{B} 5$ were examined in a random order.

The cumulative curves (Fig. 5) record the total number of species taken as the area sampled is increased. The curves rise steeply at first; and clearly a sample of less than $\frac{1}{2} \mathrm{~m}^{2}$, the area adopted in the survey, does not give an adequate qualitative sample.

Williams (I950) has analysed the occurrence of species of plants in quadrats. He has shown that if the number of species taken is plotted against the log of area (or number of quadrats), a straight-line relationship is approached. Fig. 6 shows the results of plotting against log area for the sets of samples under discussion. Each gives a straight-line relationship. From the slope of the lines it is possible to predict the number of species that will be taken in increasingly larger samples. Thus doubling the area sampled increases the 
number of species by the following amounts: St B 5, I2; Whitsand Bay, 7; Bigbury Bay, $4 \frac{1}{2}$; Thisted Bredning, $2 \frac{1}{2}$.

It is doubtful if any useful purpose would be served by analysing the occurrence of so-called 'characteristic' species in these samples since these may be by no means common on the grounds. A species may be characteristic of a community without necessarily being at all abundant, and while no doubt the ideal characteristic species are both restricted to a particular set of conditions and very common where they occur at all, it may be necessary to label a community by species of comparatively low density. Thus the Venus communities of Ford are based on species which are by no means abundant on the grounds in question, and may frequently be absent from the grab samples at a station.

The curves in Fig. 5 would not reach an asymptote until every part of the ground would have been brought up by the sampler. There are always rare species which are scarcely ever taken, and the number of species on a ground may be added to by immigrants from neighbouring grounds.

Some species, seldom taken in grab hauls, are common in trawl or dredge hauls which cover a much larger area of the bottom. An under-water photographic survey of the sea-bed off Plymouth has recently been made by Vevers (I95I), who gives figures for the densities of members of the epifauna identified in the photographs. These are in general relatively scarce; thus at position $\mathrm{L}_{4}$, mid-way between the Eddystone and Plymouth breakwater light, the mean density of certain species was: Asterias rubens: I individual in I0.4 m. ${ }^{2}$; Porania pulvillus: I in $83 \mathrm{~m} .^{2}$; Ophiura texturata: I in $20.8 \mathrm{~m} .{ }^{2}$; Chlamys opercularis: I in $7.5 \mathrm{~m} .^{2}$; Turritella communis: $\mathrm{I}$ in $83 \mathrm{~m}^{2}$; Eupagurus prideauxi: $\mathrm{I}$ in $83 \mathrm{~m}^{2}$; Hyalinoecia tubicola: $\mathrm{I}$ in $83 \mathrm{~m}^{2}$; Cellaria sp.: $\mathrm{I}$ in $3 \mathrm{~m} .{ }^{2}$.

In the same way certain members of the infauna must occur so rarely as seldom to be taken by the sampler.

\section{Variability of samples at a station}

The variability in the samples taken at a station was studied by means of twenty successive hauls taken with the double-scoop sampler at B5. Each scoop-full was kept separately and identified. In this way not only could the fauna of successive hauls be compared, but also that in the two adjacent samples taken in each haul.

Details were as follows:

5. xii. 50. Station $\mathrm{B}_{5}$. Marker float anchored at this position, the hauls being made as the ship drifted away from it. After every five hauls the ship steamed back to the mark, so that the samples are positioned along four radiating lines. The extent of drift was estimated after each set of five hauls: (i) 0.25 mile S. from float; (ii) 0.25 mile S.S.E.; (iii) 0.5 mile S.E.; (iv) 0.5 mile S.E.

Wind: light north breeze, freshening during the sampling.

Sieve: $\mathrm{r} \cdot 2 \mathrm{~mm}$.

The samples were numbered serially-thus nos. I-Io represent the first five pairs of samples, and nos. I and 2 are the two scoop-fulls from the first haul. 


\section{Table IV. Bigbury Bay. Species taken in Successive Hauls OF THE $\frac{1}{20} M .^{2}$ SCOOP-SAMPLER}

(The specific identity of the single specimen of Phacoides in haul 7 is uncertain. Names in brackets have not been included as data for Figs. 5 and 6.)
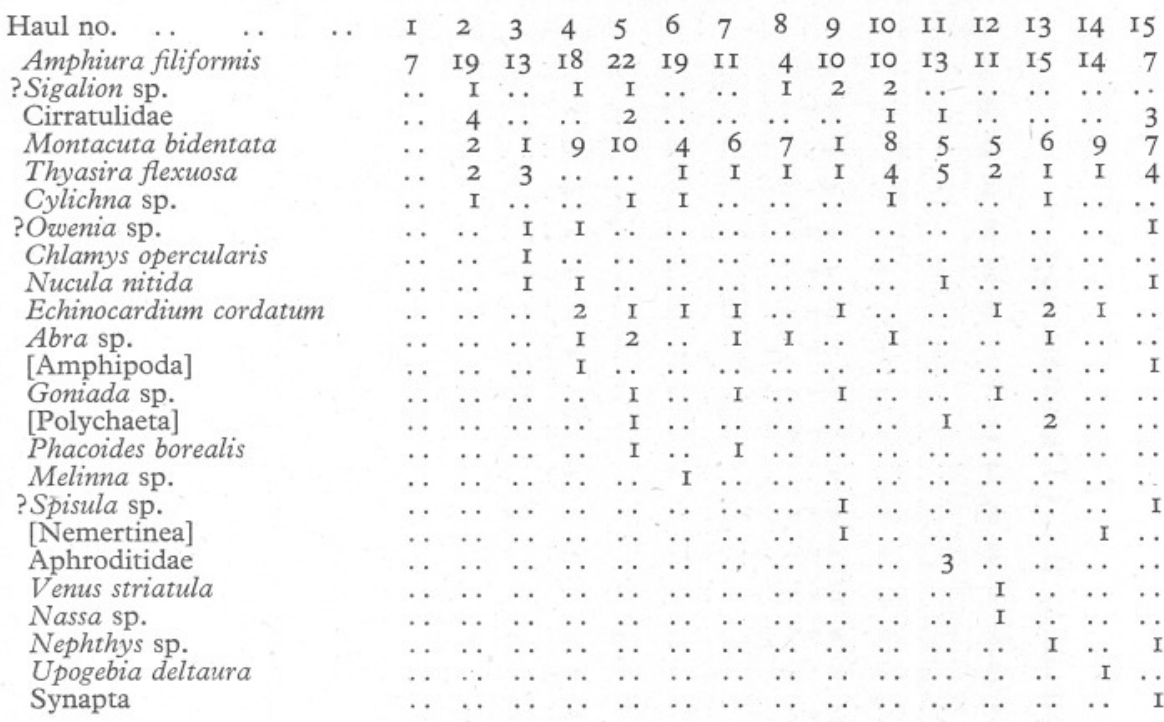

\section{Table V. Whitsand Bay. Species taken in Successive Hauls OF THE $\frac{1}{20} M .^{2}$ SCOOP-SAMPLER}

(Names in brackets have not been included as data for Figs. 5 and 6. Numbers in brackets indicate that the specific identity is uncertain.

Haul no.
?Cardium echinatum
Cochlodesma praetenue
Mactra corallina
Nephthys sp.
Magelona papillicornis
Bathyporeia tenuipes
Urothoë grimaldii var. poseidonis
Tellina fabula
?Amphitur filiformis
Natica poliana
[Nemertinea]
[Polychaeta]
Nucula nitida
Eteone picta
[Amphipoda]
Eunicidae
?Ovenia sp.
? Abra sp.
Nototropis vedlomensis
Siphonoecetes colletti
Leucotho lilljeborgi
Dosinia lupinus
$[$ Lamellibranchia]
Bathyporeia elegans
Echinocardium cordatum
Montacuta ferruginosa
Phyllodocidae
Phascolion strombi
Cirratulidae
Ensis arcuatus
Leucothoë spinicarpa
Cumacea
Gari fervensis

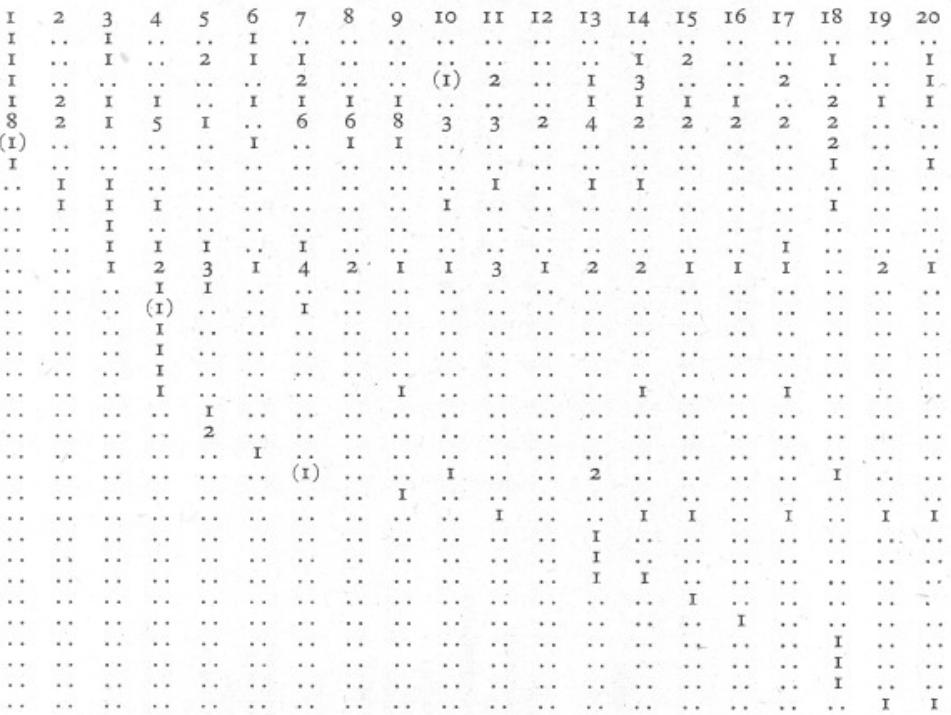


Table VI. Fauna of Successive Samples at B 5, 5 December i950

Sample no.

$\begin{array}{lllllllllllllllllllllllllllllllllllllllllllllll}\text { I } & 2 & 3 & 4 & 5 & 6 & 7 & 8 & 9 & \text { 10 } & \text { II } & \text { I2 } & 13 & 14 & 15 & 16 & 17 & 18 & 19 & 20 & 21 & 22 & 23 & 24 & 25 & 26 & 27 & 28 & 29 & 30 & 31 & 32 & 33 & 34 & 35 & 36 & 37 & 38 & 39 & 40 & \text { Total }\end{array}$

COELENTERAT
[Hydroid]

Virgularia mirabilis

Cerianthus lloyd

Edwardsia

Lumbriconereis sp.

Magelona papillicornis

Chaetopterus variopedatus

Maldanidae

Pectinaria auricoma

Pectinaria koreni

[Polychaeta indet.]

GEPHYREA

Phascolion strombi

ARTHROPODA

Ampelisca tenuicornis

Ampelisca brevicornis

Bathyporeia tenuipes

Urothoe elegans

Harpinia antennaria

Cheirocratus intermedits

Acidostoma obesum

Leucothoe sp. ${ }^{\star}$

Erichthonius brasiliensis

[Decapoda, callianassid]

[Decapod larva]

[Mysidacea]

['Prawn']

Galathea sp.

Portunus holsatus

Ebalia sp.
[Pyenogonida]

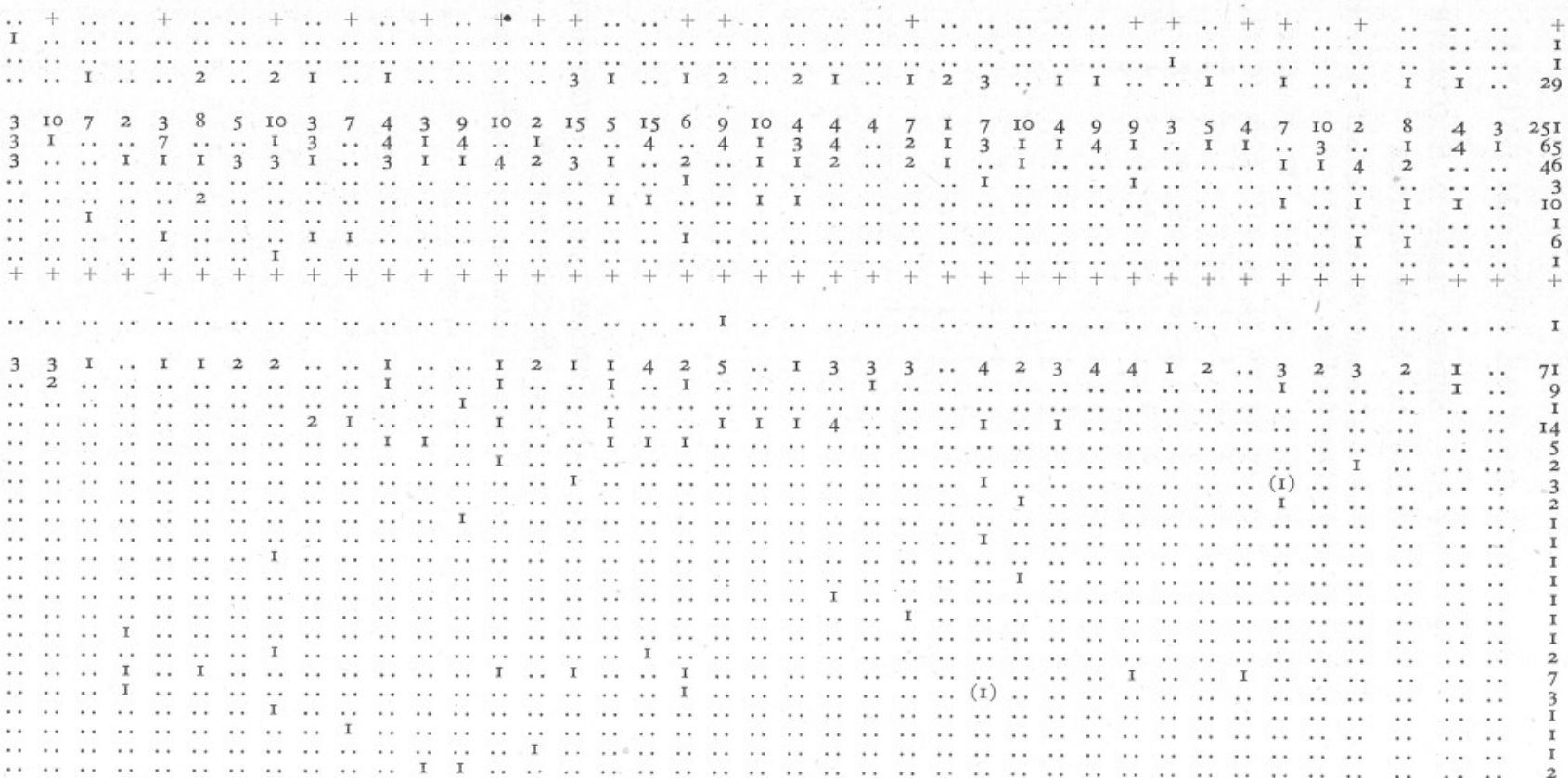




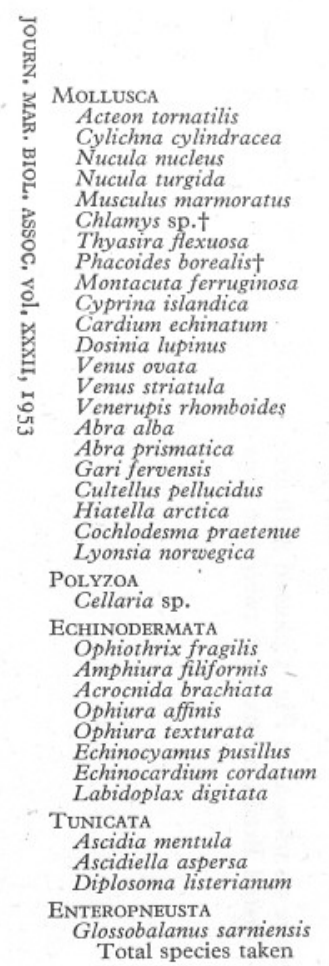

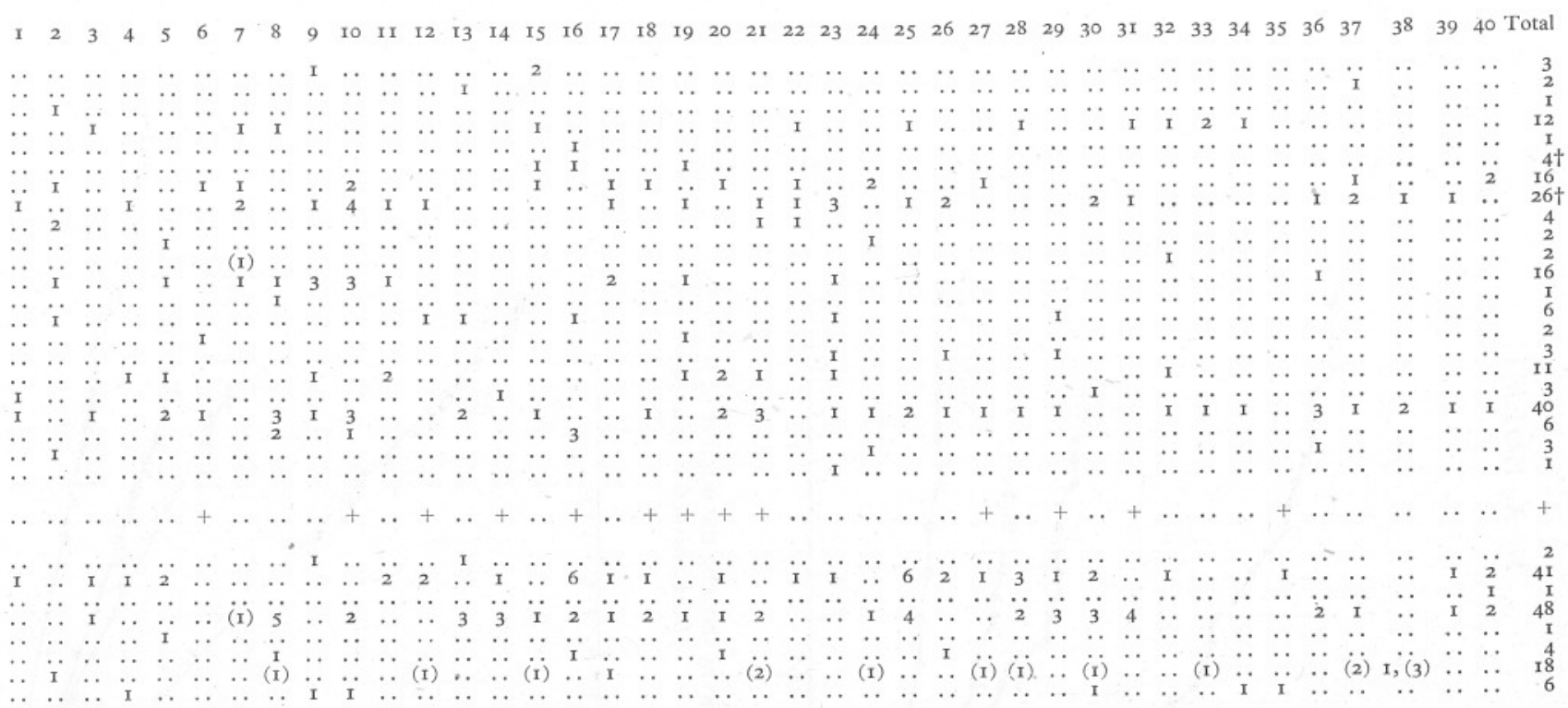

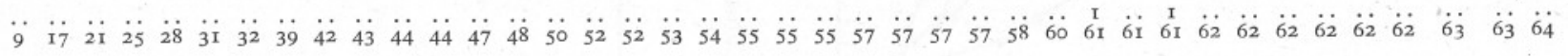
See p. 25 .

The totals in the right-hand column are corrected.

Names in brackets have not been used as data for Figs $r 5$ and 6 . Numbers in brackets indicate that the specific identity is uncertain. 


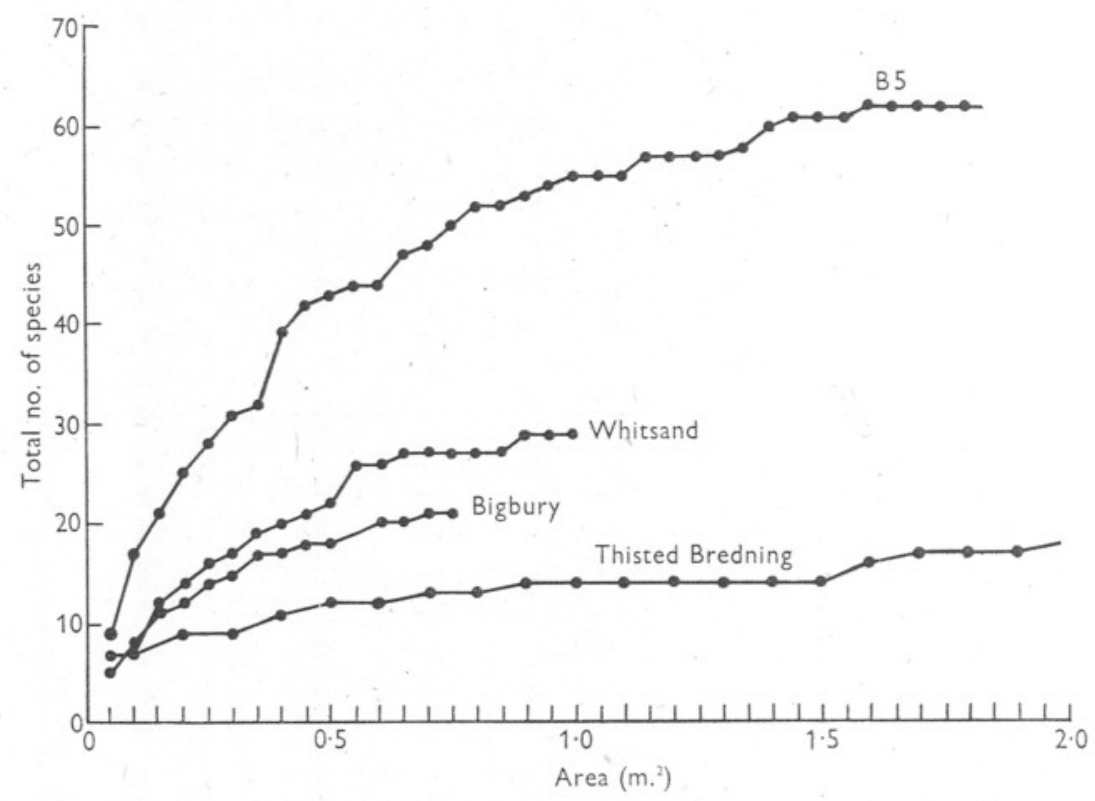

Fig. 5. Cumulative curves showing the number of species taken in successive samples of the sea-bed in four localities.

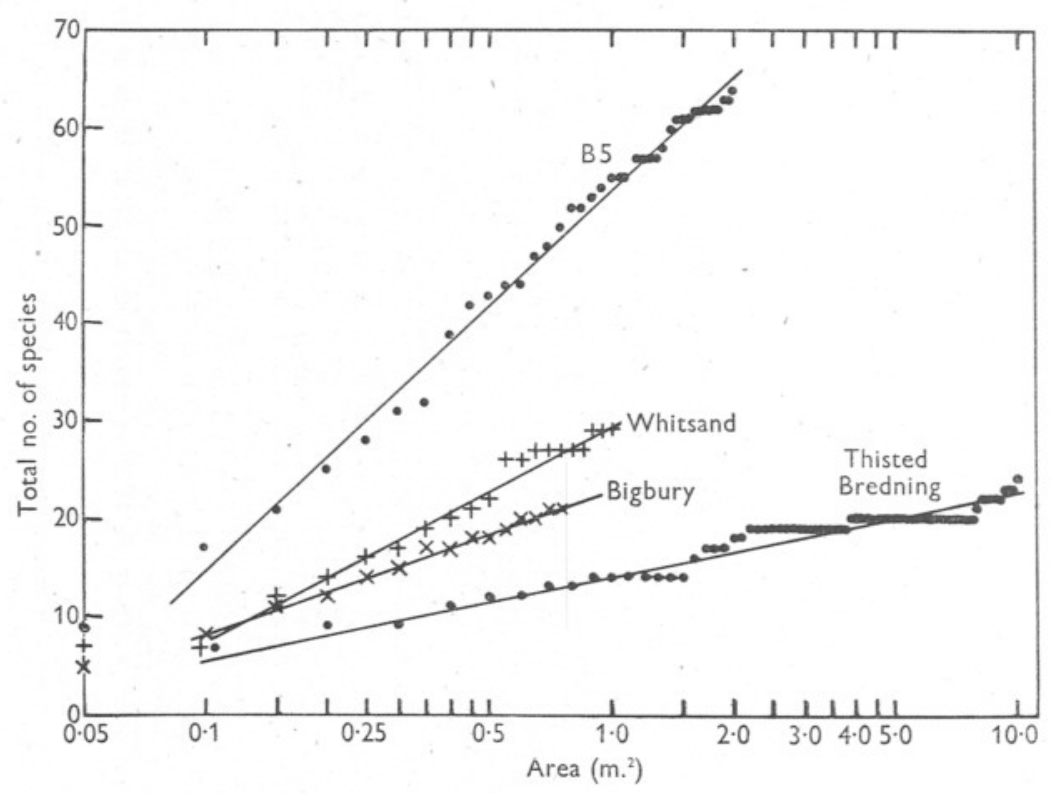

Fig. 6. The same samples as in Fig. 5 plotted with area on a log scale. Note that the samples from Thisted Bredning are each twice the area of those at the other stations. 
The fauna is shown in Table VI. Most of the species occur at rather low densities, and there are no signs of gross aggregation or that the samples pass through more than one 'community'. On the other hand, there seems to be almost as much variation between the pairs of samples from one haul as between samples in successive hauls.

A statistical examination has been made of the distribution of the common species. The variance for each species has been analysed as follows, that for Ophiura affinis being chosen as an example:

$\begin{array}{lccccc}\begin{array}{l}\text { Source of } \\ \text { variation }\end{array} & \begin{array}{c}\text { Sum of } \\ \text { squares }\end{array} & \begin{array}{c}\text { Degrees of } \\ \text { freedom }\end{array} & \begin{array}{c}\text { Mean } \\ \text { square }\end{array} & \begin{array}{c}\text { Variance } \\ \text { ratio }\end{array} & \text { Probability } \\ \text { Successive hauls } & 37.4 & \text { I9 } & \text { I.97 } & 1.64 & 0.05-0.02 \\ \text { Pairs of samples } & 34.9 & \text { I9 } & \text { I.84 } & \text { I.53 } & - \\ \text { Residual } & 0.1 & \text { I } & 0.10 & 0.08 & - \\ \quad \text { Total } & 72.4 & 39 & \text { I.86 } & 1.55 & 0.02-0.01\end{array}$

The variance between successive hauls is a measure of the large-scale patchiness of the fauna, there being perhaps I00 or 200 yards distance between each haul. The variance between the pairs of samples taken in each haul is a measure of distribution on a small scale, and there is a residual variance due to any differential sampling by the two scoops. Since no record was made of which of each pair of samples came from either scoop, this residual variance should not be significant. Analyses for the more frequent species to be compared against the expected random variance given by the Poisson distribution are given in Table VII.

As might be expected the variance between hauls tends to be greater, and therefore more frequently significant, than that between the pairs of samples from a single haul. An exception is Magelona papillicornis where the variance between pairs of samples is significant, but that between hauls is not.

A measure of the degree of patchiness is given by Fisher's 'coefficient of dispersion' (used by Holme, I950 $b$ ), which equals the Variance Ratio. This tends to unity in a randomly distributed population, to less than unity in an evenly distributed population, and to more than unity if there is aggregation. Treating the forty samples separately, the coefficients have been calculated for the same species (Table VII). Although significantly high for six species, the coefficients do not indicate any great degree of aggregation. Edwardsia, Ampelisca tenuicornis, Thyasira, and Cultellus appear to have a random distribution.

On this ground the fauna is sufficiently well dispersed for repeatable results to be obtained; but closer inshore the grounds are so patchy that this is not possible.

\section{Seasonal changes}

Most of the collections were made in the summer months, and no account has been taken of any seasonal variation in the fauna. 
Blegvad (I925) found a seasonal variation in the Macoma and Abra communities of the enclosed Danish Fjords, but in more open waters the variation was less marked. Cold winters seem to play a large part in reducing populations in shallow water. Steven (1930), in a grab survey of an offshore area at Plymouth, found no marked seasonal changes in the fauna, and a recent paper by Jones (I952) confirms this view from observations made off the Cumberland coast, in the Irish Sea.

\section{Table VII. Coefficients of Dispersion and Analysis of VARIANCE OF CERTAIN SPECIES FROM B 5 (SEE TABLE VI)}

Significant coefficients of dispersion are in bold type (test of significance $I \pm 0.4586$ ). Only significant probabilities are given.

Edwardsia sp.

Lumbriconereis sp.

Magelona papillicornis Magelona cincta

Ampelisca tenuicornis Bathyporeia tenuipes

Thyasira flexuosa

Dosinia lupinus

Cultellus pellucidus Amphiura filiformis

Ophiura affinis

\begin{tabular}{|c|}
\hline $\begin{array}{l}\text { efficient } \\
\text { ispersion } \\
\mathbf{I} \cdot 060 \\
\mathbf{I} \cdot \mathbf{8 8 8}\end{array}$ \\
\hline $\begin{array}{l}\mathbf{1} \cdot 8 \mathbf{5 2} \\
\mathrm{I} \cdot \mathbf{2 7 3}\end{array}$ \\
\hline $\begin{array}{l}I \cdot I I 2 \\
I \cdot 692\end{array}$ \\
\hline $\begin{array}{l}I \cdot 000 \\
\mathbf{I} \cdot \mathbf{5} \mathbf{3}\end{array}$ \\
\hline $\begin{array}{l}0.872 \\
\mathbf{I} \cdot 926\end{array}$ \\
\hline $\mathrm{I} \cdot 547$ \\
\hline
\end{tabular}

\begin{tabular}{|c|c|c|c|}
\hline & \multicolumn{2}{|c|}{ Probability } & • \\
\hline Hauls & Scoops & Residual & Total \\
\hline $\begin{array}{l}\cdots \\
\cdots\end{array}$ & $\begin{array}{l}\text { O.OI- } \\
0.00 I\end{array}$ & $\begin{array}{l}\ldots \\
0.02- \\
0.01\end{array}$ & $<0.001$ \\
\hline $\begin{array}{l}.0 \\
0.05- \\
0.02\end{array}$ & $\begin{array}{c}<0.00 I \\
\ldots\end{array}$ & . & $\begin{array}{c}<0.00 I \\
\cdots\end{array}$ \\
\hline $\begin{array}{l}0.02- \\
0.01\end{array}$ & $\begin{array}{l}. \\
\therefore\end{array}$ & $\begin{array}{l}\cdots \\
\therefore\end{array}$ & $\begin{array}{l}\text { O.OI- } \\
0.00 I\end{array}$ \\
\hline$<0.001$ & $\begin{array}{l}\cdots \\
\cdots\end{array}$ & $\begin{array}{l}\cdots \\
\therefore\end{array}$ & $\begin{array}{l}\cdots \\
0.05- \\
0.02\end{array}$ \\
\hline $\begin{array}{l}\cdots \\
0.0 I- \\
0.00 I\end{array}$ & $\begin{array}{l}\ldots \\
0.05- \\
0.02\end{array}$ & $\begin{array}{l}\cdots \\
\cdots\end{array}$ & $<0.00 I$ \\
\hline $\begin{array}{l}0.05- \\
0.02\end{array}$ & . & . & $\begin{array}{l}0.02- \\
0.01\end{array}$ \\
\hline
\end{tabular}

Some seasonal changes must occur coinciding with the settling and growth of young, but the larger benthic invertebrates are usually considered to have a life-span of several years and fluctuations in total population density are thus reduced.

Most of the populations studied were composed of large numbers of species, few of which occurred in abundance, and this diversity should minimize the effects of seasonal and annual fluctuations.

\section{Sieving}

The samples were washed through a gauze sieve of $2 \cdot 2 \mathrm{~mm}$. aperture on board ship, and the sievings kept for examination in the laboratory. The use of a sieve to separate the fauna from the sediment necessarily results in a lower size limit to the animals collected. With animals of a definite size and shape, e.g. Mollusca, the proportion of animals passing through the sieve is dependent on the size of the individuals, but many worms actively crawl through the meshes and quite large individuals may be lost during a prolonged 
sieving. It is advisable to wash out the contents of the sieve into a jar as often as possible to minimize such losses.

While a finer meshed sieve would undoubtedly retain many more small amphipods, worms, etc., the $2.2 \mathrm{~mm}$. sieve was used because of the high percentage of coarse particles at some stations which soon clog a finer sieve.

Table VIII. Numbers and Weights of Animals at C4 (7 November i950) AFTER WASHING SAMPLE THROUGH FIRST THE $2 \cdot 2 \mathrm{MM}$. AND THEN THE I.2 MM. SIEVE

(Numbers in brackets indicate doubtful identity.)

\begin{tabular}{|c|c|c|c|c|}
\hline & & $\mathrm{mm}$. & & $\mathrm{mm}$. \\
\hline 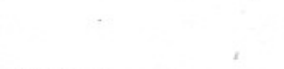 & No. & $\begin{array}{l}\text { Dry weight } \\
\text { (g.) }\end{array}$ & No. & $\begin{array}{l}\text { Dry weight } \\
\text { (g.) }\end{array}$ \\
\hline Hydroid & + & 0.003 & .. & .. \\
\hline Anemone & I & 0.083 & $\cdots$ & \\
\hline Polychaeta & 6 & 0.085 & + & 0.31 \\
\hline Diastylis laevis & . & .. & (5) & \\
\hline Isopoda & .. & .. & I & \\
\hline Ampelisca tenuicornis & .. & .. & 5 & \\
\hline $\begin{array}{l}\text { Ampelisca diadema } \\
\text { Bathyporeia temuipes }\end{array}$ & $\cdots$ & $\cdots$ & I & 0.002 \\
\hline $\begin{array}{l}\text { Bathyporeia tenuipes } \\
\text { Harpinia antennaria }\end{array}$ & $\begin{array}{l}\cdots \\
.\end{array}$ & $\begin{array}{l}\ldots \\
.\end{array}$ & $\begin{array}{l}6 \\
2\end{array}$ & \\
\hline Photis longicaudata & I & $<0.001$ & .. & \\
\hline Pycnogonida & . & .. & 4 & \\
\hline Nucula turgida & .. & .. & 8 & \\
\hline $\begin{array}{l}\text { Thyasira flexuosa } \\
\text { Dosinia lupinus }\end{array}$ & 4 & 0.022 & 7 & \\
\hline $\begin{array}{l}\text { Dosinia lupinus } \\
\text { Venus striatula }\end{array}$ & 2 & 0.003 & (I) & \\
\hline $\begin{array}{l}\text { Venus striatula } \\
\text { Mysia undata }\end{array}$ & I & 0.001 & $\cdots$ & \\
\hline $\begin{array}{l}\text { Mysia undata } \\
\text { Abra alba }\end{array}$ & 2 & 0.16 & .. & \\
\hline Abra alba & I & 0.006 & & 0.022 \\
\hline Abra prismatica & I & 0.022 & (7) & \\
\hline Gari fervensis & . & & 3 & \\
\hline Cultellus pellucidus & I & 0.042 & I & \\
\hline Hiatella arctica & I & 0.001 & & \\
\hline Thracia sp. & 4 & 0.011 & Io & \\
\hline Cellaria sp. & + & 0.005 & & . \\
\hline Amphiura filiformis & I & 0.001 & 7 & \\
\hline Ophiura affinis & I & 0.001 & (I) & 0.001 \\
\hline Echinocyamus pusillus & ․ & & I & \\
\hline Cucumaria elongata & I & 0.073 & .. & .. \\
\hline Total & & 0.52 & & 0.34 \\
\hline
\end{tabular}

The same mesh was employed at all stations to ensure a uniformity in sampling technique. Petersen \& Boysen Jensen (I9I I) used a sieve of I. $5 \mathrm{~mm}$. aperture for sieving deposits consisting mainly of fine particles, and where the soil is fine no coarser mesh should be employed.

The use of a series of sieves, such as the Challenger series, has not been found practicable, as the smaller meshed sieves are liable to clog and overflow, and some of the smaller animals are thereby lost.

On 7 November 1950 station $\mathrm{C}_{4}$ was sampled a second time. The sample, which was of fine sand, was sieved through first a $2 \cdot 2 \mathrm{~mm}$. and then a I.2 $\mathrm{mm}$. 
sieve. The fauna taken in each sieve is shown in Table VIII. In this sample the coarse sieve failed to retain a high proportion of the individuals. Of the total dry weight, nearly two-fifths passed the $2 \cdot 2 \mathrm{~mm}$. sieve and was retained by the finer mesh. At most stations, however, the relative losses are probably not as high as this. In the twenty stations worked, $64.4 \%$ of the total dry weight was made up of fairly large individuals, each weighing more than 0.2 g. dry (p. 38), whereas at this station there were no individuals of this size. The previous samples taken at $\mathrm{C}_{4}$ had given a total of $5.7 \mathrm{~g}$. per $\frac{1}{2} \mathrm{~m} .{ }^{2}$ (p. 35), and the second series has an exceptionally low dry weight. If we take the losses at each station through using the $2.2 \mathrm{~mm}$. sieve as about $0.4-0.5 \mathrm{~g}$., or say $10 \%$ of the total taken, a reasonable correction can be made.

The animals lost through the $2 \cdot 2 \mathrm{~mm}$. sieve correspond to the 'small macrobenthos' of Mare (1942). In the Rame mud a mile or two north of A2 she found that small polychaetes, etc., retained on the $\mathrm{I} \mathrm{mm}$. sieve represented about $30.6 \%$ of the total (fresh) weight of macrobenthos. Polychaetes are abundant in the Rame mud, and a smaller percentage would therefore be expected for other grounds.

\section{Biomass estimations}

Any estimate of the productivity of a community must start with an assessment of the 'standing crop', that is, the quantity of living tissue present at any one time. Owing to the very different sizes of species and individuals, an estimate of their numerical density is insufficient, and comparisons are best made in terms of weight.

The biomass may be expressed either as: (i) the 'fresh weight', i.e. the weight of fresh tissue after surface moisture has been blotted off, the weight of mollusc shells may or may not be included; (ii) the dry weight, shells usually being excluded from the total.

In this investigation the dry weight of the specimens has been determined, and is here defined as the weight of the residue obtained after evaporation at I I $0^{\circ} \mathrm{C}$. to a (more or less) constant weight, surface moisture having previously been removed. The weight of all substances soluble in dilute hydrochloric acid has been excluded from the total. The dry weight thus includes chitinous or similar non-calcareous skeletal structures, inorganic salts in the blood and tissues, and gut contents (except in Echinocardium), but excludes all calcareous structures.

The animals were usually preserved in formalin on board ship, but were transferred to and stored in $70 \%$ alcohol within a day or two. The 'alcohol weight' was determined from preserved specimens by blotting off surface moisture with filter-paper, and weighing as quickly as possible to the nearest centigram.

During preservation certain constituents of the tissues dissolve out into the alcohol. To find the relation of dry weight to alcohol weight two or three 
specimens of certain species were preserved in $70 \%$ alcohol for at least a week. The preserved animals were then dried at $110^{\circ} \mathrm{C}$. overnight and to the dry weight was added that of the residue obtained from evaporating the alcohol.

The dry weight has been calculated as a percentage of the alcohol weight for a number of species (Table IX). For the rest a value of $27 \cdot 72 \%$ has been taken, being the mean of determinations for species not having a calcareous skeleton. It was more convenient to measure the size rather than the weight

\section{Table IX. Dry Weight Expressed as a Percentage of ALCOHOL WeIGHT}

(Species marked with an asterisk were treated with acid before the dry weight was determined. Figures in italics are assumed or approximate percentages. The figure given for Amphipoda is derived from Molander (1928), and allows for matter dissolved out by the alcohol. It appears to be too low, but in any case the 'biomass' of the amphipod population is extremely small.)

\begin{tabular}{|c|c|}
\hline $\begin{array}{l}\text { COELENTERATA } \\
\text { Hydroids and anemones } \\
\text { Alcyonium }^{\star}\end{array}$ & $\begin{array}{l}27 \cdot 7^{2} \\
10 \cdot 00\end{array}$ \\
\hline $\begin{array}{l}\text { PolychaEta } \\
\text { Chaetopterus } \\
\text { All other spp. }\end{array}$ & $\begin{array}{l}25 \cdot 24 \\
27 \cdot 72\end{array}$ \\
\hline $\begin{array}{l}\text { CRUSTACEA } \\
\text { Amphipoda etc. } \\
\text { Callianassa (and other Macrura) } \\
\text { Gonoplax }^{\star} \text { (and other Brachyura) }\end{array}$ & $\begin{array}{r}4.12 \\
19.83 \\
24.20\end{array}$ \\
\hline $\begin{array}{l}\text { MollusCa } \\
\text { Cyprina islandica } \\
\text { Solecurtus chamasolen } \\
\text { Tellina crassa } \\
\text { All other spp. }\end{array}$ & $\begin{array}{l}28 \cdot 14 \\
31 \cdot 05 \\
25 \cdot 74 \\
27 \cdot 72\end{array}$ \\
\hline $\begin{array}{l}\text { PolyzoA } \\
\text { Cellaria }\end{array}$ & $3 \cdot 43$ \\
\hline $\begin{array}{l}\text { ECHINODERMATA } \\
\text { Ophiothrix fragilis } \\
\text { Amphiura }{ }^{\star} \text { (and other Ophiuroidea) } \\
\text { Echinocardium }{ }^{\star} \text { (and Echinocyamus) } \\
\text { Cucumaria } \\
\text { Leptosynapta }\end{array}$ & $\begin{array}{r}14 \cdot 56 \\
5.54 \\
2 \cdot 29 \\
14.66 \\
24 \cdot 16\end{array}$ \\
\hline $\begin{array}{l}\text { CEPHALOCHORDATA } \\
\text { Amphioxus }\end{array}$ & $28.4 \mathrm{I}$ \\
\hline
\end{tabular}

of some species, and by a series of determinations of dry weight a factor was obtained for converting a size measurement directly into terms of dry weight.

(The conversion factors from alcohol to dry weight differ from those given by Petersen \& Boysen Jensen (I9I I, p. 52). They apparently added the weight of the material, obtained from evaporating the alcohol, to the total after applying their conversion factor. In the present investigations the quantity dissolved in the alcohol is allowed for in the conversion factor.) 
A number of observations were made to assess the validity of these techniques:

(i) It was found that after about a week most of the soluble substances had dissolved out into the alcohol. A change to fresh alcohol did not greatly increase the total amount dissolved out.

(ii) Provided that a reasonable quantity of preservative was used, the amount of dry matter dissolved out of the tissues was not dependent on the relative volumes of the animals and the spirit.

(iii) About half as much again was dissolved out if $96 \%$ alcohol was used in preservation.

(iv) Weight of gut contents. Where a species contains much sand in the gut, a considerable error might be introduced in dry-weight determinations. A number of alcohol-preserved animals were weighed before and after ignition. The residue after ignition is ash, together with any sand from the gut. The weights after ignition, expressed as percentages of the alcohol weight, were:

$\begin{array}{lll}\text { Chaetopterus variopedatus } & \text { (Polychaeta) } & \mathrm{I} \cdot 09 \% \\ \text { Solecurtus chamasolen } & \text { (Lamellibranchia) } & \mathrm{I} \cdot 00 \% \\ \text { Abra alba } & \text { (Lamellibranchia) } & 7 \cdot 43 \% \\ \text { Ophelia bicornis } & \text { (Polychaeta) } & 23.93 \% \\ \text { Miscellaneous small worms from bottom-sampler hauls: } 2 \cdot 23 \% .\end{array}$

Taking ash as $\mathrm{I} \%$ of the alcohol weight (i.e. assuming that the Chaetopterus and Solecurtus residue was entirely 'organic ash'), the rest is sand. Ophelia is a depositfeeding worm in which the gut can be seen to be full of sand, and represents a maximum figure. Abra feeds on detritus collected from the soil surface, and might be expected to take in some sand with the food. Chaetopterus and Solecurtus both draw their food from material in suspension just off the bottom, and so probably take in very little sand under normal conditions.

An estimate that the alcohol weights include $5 \%$ of sand in the guts of animals seems a reasonable overall estimate.

(v) Calcareous skeletons. The shells of molluscs were removed before weighing, but with other forms it was necessary to determine an alcohol weight which included the skeleton. To determine the dry weight, the skeleton was then dissolved by placing the animal in dilute hydrochloric acid, the mixture being filtered, washed with distilled water, dried and weighed.

Treatment with dilute acid did not appear to release into solution appreciable quantities of non-calcareous substances within the tissues. Treatment of a noncalcareous organism (the polychaete Nereis) with acid did not alter the alcohol weight/ dry weight ratio, but it was thought that where an animal had calcareous spicules embedded in the tissues, some loss might result from the mechanical break-up of cells due to formation of bubbles of carbon dioxide.

For non-calcareous animals there is a fairly constant proportion of the total dry weight found in solution in the alcohol. If acid treatment after determination of the alcohol weight resulted in the loss of material into the acid solution, a resultant change in the ratio of the weight of dried animal tissue to total dry weight would occur. In six species which were not acid treated, the percentages of the total dry weight found in the dried preserved animal were: Nereis diversicolor, 59.04; Amphioxus lanceolatus, 68.33; Solecurtus chamasolen, $64 \cdot 78$; Tellina crassa, $5 \mathrm{I} \cdot \mathrm{I} 3$; Chaetopterus variopedatus, 56.53; Cyprina islandica, 73.69; Mean: 62.25 . In four species in which the skeleton was dissolved in acid, the percentages were: Ophiothrix fragilis, 50.06; Callianassa subterranea, 58.28; Gonoplax rhomboides, 54.90; Cucumaria elongata, 69.55; Mean: $58 \cdot 20$. There is therefore no evidence of any considerable loss due to acid treatment. 
In Echinocardium cordatum the alcohol weight is made up largely of both calcium carbonate in the skeleton and sand in the gut, plus a certain amount of sea water inside the test. After acid treatment, as above, the residue was ignited and the percentage of sand calculated. Allowance for the sand content of the gut has been made in the factor given in Table IX.

\section{Nomenclature}

Nomenclature is that of the Plymouth Marine Fauna (Marine Biological Association, I93I), except for the Mollusca, which are named as in Winckworth's (I932) list of British marine Mollusca. The following species are not in the Plymouth Marine Fauna:

PolychaETA

Sigalion mathildae Audouin \& M.-Edwards* (see Fauvel, I923).

Magelona cincta (Ehlers) (see Mare, I942, p. 542).

\section{AMPHIPODA}

Ampelisca diadema (A. Costa) (see Chevreux \& Fage, 1925).

Bathyporeia elegans Watkin (see Watkin, I938).

B. tenuipes Meinert (see Watkin, 1938).

Urothoë grimaldii Chevreux var. poseidonis Reibisch (see Chevreux \& Fage, I925, p. IOO as var. inermis).

Urothoë elegans Bate (see Chevreux \& Fage, I925).

Leucothoë lilljeborgi Boeck (see Chevreux \& Fage, 1925).

Leucothoë sp. (the undescribed species mentioned in Spooner, I950, p. 249).

LAMELLIBRANCHIA

Cochlodesma praetenue ${ }^{\star}$ (Montagu) (see Forbes \& Hanley, I853).

\section{ENTEROPNEUSTA}

Glossobalanus sarniensis (Koehler)* (see Koehler, I886).

Species marked with an asterisk $\left({ }^{\star}\right)$ are first records for the Plymouth area.

\section{Station $A$ I Details of Stations and Collections}

$50^{\circ} 19^{\prime} 40^{\prime \prime}$ N., $4^{\circ} 14^{\prime} 45^{\prime \prime}$ W. Clean sand (Table I, Fig. 2). Depth c. I5 m. (at all stations the depth is given from soundings on the Admiralty Chart of the area). 18. x. 50. Area: $0.5 \mathrm{~m}^{2}$. Sieve: $2.2 \mathrm{~mm}$. Ship anchored.

This station is slightly out of line with the other stations to avoid a 'dumping ground'. The fauna (Table X) is similar to that given in Table V, taken at a position about half a mile distant.

The bottom in this part of Whitsand Bay is very patchy, areas of rock or gravel occurring in places. The small polychaete Magelona papillicornis is common, and some specimens were probably lost through the sieve. $M$. cincta, a rather larger worm, occurs here and at several other stations. It was first recorded from Plymouth by Mare (1942); it is probably not new to the 
area, and may have been confused with $M$. papillicornis in earlier records (D. P. Wilson, personal communication).

The total dry weight at this station is $\mathrm{I} \cdot 5 \mathrm{~g} . / \frac{1}{2} \mathrm{~m} .{ }^{2}$, which is lower than for most stations in the survey. There were no large individuals apart from five specimens of Echinocardium.

Table X. Station A i. Numbers and Dry Weights per $\frac{1}{2}$ M. ${ }^{2}$

(Numbers in brackets are approximate. $j$ : young individuals.)

Nemertinea indet.
Sigalion mathildae
Aphroditidae
Phyllodocidae
Nephthys sp.
Glycera sp.
Magelona papillicornis
Magelona cincta
Spionidae
Polychaeta indet.
Diastylis laevis
Ampelisca brevicornis
Gastrosaccus sanctus

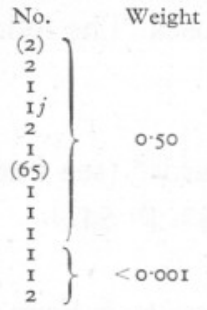

Portunus sp.
Natica poliana
Philine sp.
Nucula turgida
Dosinia lupinus
Tellina fabula
Ensis ensis
Ensis arcuatus
Mactra corallina
Cellaria sp.
Ophiura affinis
Echinocardium cordatum
Total dry weight

Table Xi. Station A2. Numbers and Dry Weights Per $\frac{1}{2}$ M. ${ }^{2}$

(Where it has been necessary to assume the weigit of an individual, either because it was badly fragmented

\begin{tabular}{|c|c|c|c|c|c|}
\hline & No. & Weight & & No. & Weight \\
\hline $\begin{array}{l}\text { Hydroid } \\
\text { Anemones }\end{array}$ & + & $\begin{array}{l}0.092 \\
0.73\end{array}$ & $\begin{array}{l}\text { Alpheus ruber } \\
\text { Callianassa subterranea }\end{array}$ & 2 & $\begin{array}{l}0.93 \\
0.025\end{array}$ \\
\hline Eunice haras: $i$ & I & $7 / 3$ & Portunus depurator & $\begin{array}{l}1 \\
1\end{array}$ & $\begin{array}{l}0.025 \\
0.42\end{array}$ \\
\hline $\begin{array}{l}\text { Maldanidae } \\
\text { Melinna palmata }\end{array}$ & $\stackrel{1}{1}$ & 0.99 & $\begin{array}{l}\text { Chlamys sp. } \\
\text { Cucumaria elongata }\end{array}$ & ${ }_{2} j$ & $\begin{array}{l}0.001 \\
0.67\end{array}$ \\
\hline $\begin{array}{l}\text { Polychaeta indet. } \\
\text { Phyllochaetopterus tubes }\end{array}$ & I & & Leptosynapta inhaerens & 2 & 0.97 \\
\hline Scalpellum scalpellum & I & 0.011 & Total dry weight & & 48 \\
\hline
\end{tabular}

\section{Station $A_{2}$}

$50^{\circ} \mathrm{I} 7^{\prime} \mathrm{N} ., 4^{\circ} \mathrm{I} 5^{\prime} \mathrm{W}$. Very fine muddy sand (Table I, Fig. 2). Depth: $46 \mathrm{~m}$. 26. vi. 50 . Area: $0.5 \mathrm{~m}^{2}$. Sieve: $2.2 \mathrm{~mm}$. Ship drifting at this and at subsequent stations.

This station on the southern edge of the 'Rame mud' is characterized by the abundance of Melinna palmata, and the presence of Alpheus ruber, Callianassa subterranea, Cucumaria elongata and Leptosynapta inhaerens, which together constitute a large proportion of the total dry weight (Table XI). Lamellibranchs are scarce in this deposit, the only species commonly taken in dredgings being Solecurtus chamasolen.

The station is somewhat to the south of stations worked in the Rame mud by Ford (1923) and Mare (1942). The latter estimated a total of over I00 $\mathrm{g}$./ m. ${ }^{2}$ of fresh tissue in the Rame deposit (see p. 43).

\section{Station $\mathrm{A}_{3}$}

$50^{\circ} 15^{\prime}$ N., $4^{\circ} 15^{\prime}$ W. Hauls nos. I, 2 and 6 on clean medium-grade sand, hauls 3-5 on mixed muddy sand and gravel. Depth: $5 \mathrm{I} \mathrm{m.} \mathrm{26.} \mathrm{vi.} 50$. Area: $0.6 \mathrm{~m}$. ${ }^{2}$. Sieve: $2 \cdot 2 \mathrm{~mm}$.

The sediment at this station is very patchy, two distinct grades of deposit being taken in the sampler. The first is a medium-grade sand with less than 
I $\%$ over $2 \mathrm{~mm}$., and $\mathrm{I} \cdot 5 \%$ silt; the second a muddy gravel with $28.9 \%$ over $2 \mathrm{~mm}$. and $7 \%$ silt (Table I and Fig. 2). The fauna (Table XII) in the different hauls probably varied somewhat, but is characteristic of the muddy sand grounds inside the Eddystone, where typical species are: the polychaetes Nephthys sp., Eunice harassi, Hyalinoecia bilineata, Lumbriconereis sp., burrowing prawns Upogebia deltaura and $U$. stellata, the lamellibranchs Dosinia lupinus, Cultellus pellucidus and Solecurtus chamasolen, and the hearturchin Echinocardium cordatum. The polyzoan Cellaria occurs in clumps and was quite abundant in some samples. Three species of Cellaria are recorded in the Plymouth Marine Fauna (Marine Biological Association, I93I), but specific identifications were not made in this survey.

Polychaeta make up about half the total dry weight. Cellaria contributes only $0.5 \mathrm{~g}$. to the total; its fresh weight being largely composed of calcium carbonate in the skeleton. The total dry weight, $4.0 \mathrm{~g} \cdot / \frac{1}{2} \mathrm{~m} .^{2}$, is rather below the average for the area.

\section{Table XII. Station A3. Numbers and Weights Per $0.6 \mathrm{M}^{2}$}

Hydroid
Anemone
Edwardsia sp.
Nemertinea indet.
Nephthys sp.
Glycera sp.
Eunice harassi
Nematonereis unicornis
Hyalinoecia bilineata
Lumbriconereis sp.
Maldanidae
Capitellidae
fasmineira elegans
Terebellidae
Polychaeta indet.

\begin{tabular}{|c|c|c|}
\hline No. & Weight & \\
\hline+ & 0.40 & Phyllochaetopterus tubes \\
\hline I & 0.53 & Owenia tube \\
\hline $2 j$ & 0.083 & Ampelisca spinipes \\
\hline $\begin{array}{l}1 \\
3\end{array}$ & & Ampelisca tenuicornis \\
\hline $\begin{array}{l}3 \\
2\end{array}$ & & $\begin{array}{l}\text { Mogerolu stellata } \\
\text { Modiolus phaseolinus }\end{array}$ \\
\hline I & & Dosinia lupinus \\
\hline I & & Cultellus pellucidus \\
\hline $\begin{array}{c}1 \\
(22)\end{array}$ & 2.0 & Cellaria sp.. \\
\hline $\begin{array}{c}(22) \\
\text { I }\end{array}$ & & $\begin{array}{l}\text { Amphiura filiformis } \\
\text { Amphipholis squamata }\end{array}$ \\
\hline 5 & & Ascidiella aspersa \\
\hline 2 & & Total dry weight $\left(0.6 \mathrm{~m} .^{2}\right)$ \\
\hline 4 & & \\
\hline
\end{tabular}

\begin{tabular}{cc} 
No. & Weight \\
4 & \multicolumn{1}{c}{$\ldots$} \\
I & \multicolumn{1}{c}{. } \\
4 \\
$2\}$ & $0.01 \mathrm{I}$ \\
I & 0.34 \\
I & 0.007 \\
I $j$ & 0.001 \\
2 & 0.050 \\
I & 0.51 \\
I & 0.014 \\
3 & 0.003 \\
I & 0.007 \\
& 4.0
\end{tabular}

\section{Station $\mathrm{A}_{4}$}

$50^{\circ} 13^{\prime}$ N., $4^{\circ} 15^{\prime}$ W. Muddy sand with small stones and shell fragments. Depth: $55 \mathrm{~m}$. I8. x. 50 . Area: $0.5 \mathrm{~m} .^{2}$. Sieve: $2.2 \mathrm{~mm}$.

As at $A_{3}$, there was considerable variation in the grade of deposit brought up in successive hauls. Two types of sediment were taken, their grades corresponding closely to those at $\mathrm{A}_{3}$ (Table I and Fig. 2).

The fauna (Table XIII) is similar to that at the previous station. Polychaete worms are common and make up over a quarter of the total weight. Three specimens of Upogebia deltaura were taken, whereas $U$. stellata was taken at $\mathrm{A}_{3}$.

The total dry weight is $6.9 \mathrm{~g}$., largely made up of Polychaeta, Upogebia, and the crab Portunus depurator.

\section{Station $A_{5}$}

$50^{\circ} \mathrm{II}^{\prime} \mathrm{N} ., 4^{\circ} \mathrm{I} 6^{\prime} \mathrm{I} 5^{\prime \prime} \mathrm{W}$. (Eddystone bearing $150^{\circ} \mathrm{T}$., 0.5 miles.) Shell gravel

(Table I, Fig. 2). Depth: c. $42 \mathrm{~m}$. 21. vii. 50 . Area: $0.5 \mathrm{~m} .{ }^{2}$. Sieve: $2.2 \mathrm{~mm}$. 
This station is situated on the Eddystone shell gravel where dredgings are frequently made for Amphioxus. This position was worked to avoid a possibly rocky ground on the east side of the reef, and since an area was selected where the fauna was known to be quite rich a slight bias is given to the results as a whole, since all but one of the other stations were selected at definite intervals irrespective of the possible nature of the ground.

Since the position is so close to the Eddystone Lighthouse, it is possible to obtain an accurate position fix, but the ship soon drifts off the ground, and while making hauls with the bottom-sampler it was necessary to steam back to the original position after two or three hauls.

\section{Table XiII. Station A4. Numbers and Weights Per $0.5 \mathrm{M}^{2}{ }^{2}$}

Hydroid
Anemone
Edwardsia sp.
Glycera $\mathrm{sp}$.
Hyalinoecia bilineata
Onuphis conchylega'
Lumbriconereis $\mathrm{sp}$.
?Ozenia sp.
Pectinaria sp.
Maldanidae
Terebellidae
Sabellidae
Polychaeta indet.
Phyllochaetopterus tubes
'Prawn'

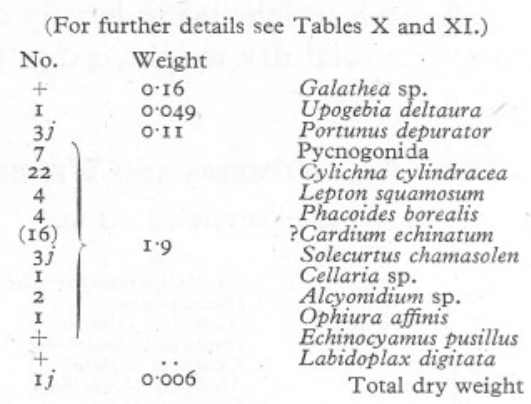

$\begin{array}{cc}\text { No. } & \text { Weight } \\ 3 j & 0.019 \\ \mathrm{I}, 2 j & 1.6 \\ \mathrm{I} & 2.0 \\ \mathrm{I} & <0.00 \mathrm{I} \\ 4 & 0.0 \mathrm{II} \\ \mathrm{I} & 0.003 \\ \mathrm{I} & 0.040 \\ \mathrm{I} j & 0.010 \\ \mathrm{I} & 0.075 \\ \mathrm{I} & 0.046 \\ 6 & 0.43 \\ \mathrm{I} & 0.002 \\ 2 & <0.00 \mathrm{I} \\ \mathrm{I} & 0.48 \\ & 6.9\end{array}$

Table XIV. Station A 5. Numbers and WeightS Per $0.5 \mathrm{M.}^{2}$

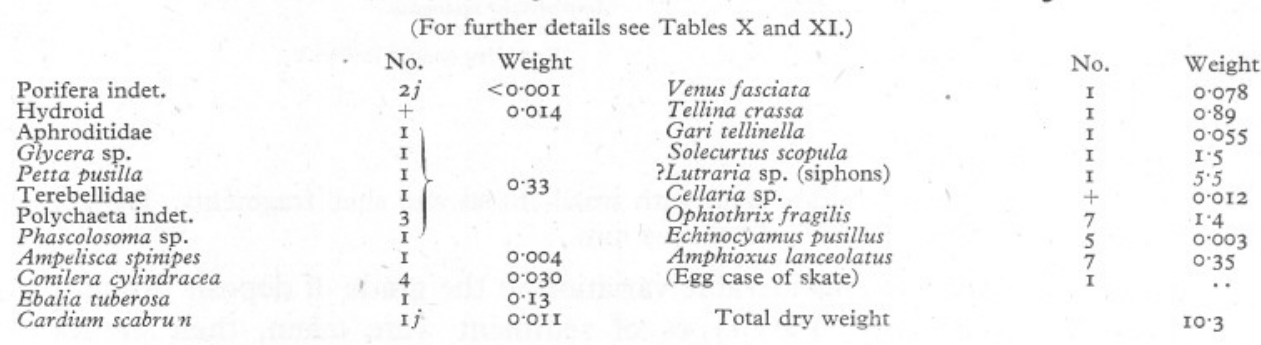

Smith (1932) has studied the fauna and deposits around the Eddystone in some detail. The species characteristic of the shell-gravel are species of the 'SpVf' (Spatangus purpureus-Venus fasciata) communities of Ford (I923).

The siphons of a large lamellibranch, probably Lutraria, were taken (Table XIV). Ford records specimens of L. magna from shell-gravel in Plymouth Sound, so these may be of the same species. The animal was judged to be adult, and was assumed to have an alcohol weight of $20 \mathrm{~g}$. (5.5 g. dry).

Polychaete worms form only a small fraction of the total dry weight, which is largely made up of moderate-sized lamellibranchs, and the Lutraria. Ophiothrix seems to be patchily distributed on this ground. 
For stations A6 and A 7 see pp. 32-33.

\section{Station B I}

$50^{\circ} \mathrm{I}^{\prime}$ N., $4^{\circ}$ I0' W. Shell gravel with coal and clinker. Depth: $3 \mathrm{I} \mathrm{m.} \mathrm{26.} \mathrm{vi.} 50$. Area: $0.1 \mathrm{~m} .{ }^{2}$. Sieve: $2 \cdot 2 \mathrm{~mm}$.

Three hauls were made, one of which brought up a sample of gravel (Table I); the other two were evidently on a rocky bottom.

A single specimen of Tellina crassa was taken with a dry weight of $0.64 \mathrm{~g}$. This is equivalent to $3.2 \mathrm{~g} \cdot / \frac{1}{2} \mathrm{~m} .{ }^{2}$.

Table XV. Station B2. Numbers and Weights Per $\frac{1}{2} M^{2}{ }^{2}$

Hydroid

Alcyonium sp.

Nemertinea indet.

Glycera sp.

Marphysa belli

Cirratulidae

Notomastus latericeus

Amphicteis gunneri

Melinna sp.

Maldanidae

Myxicola infundibulum

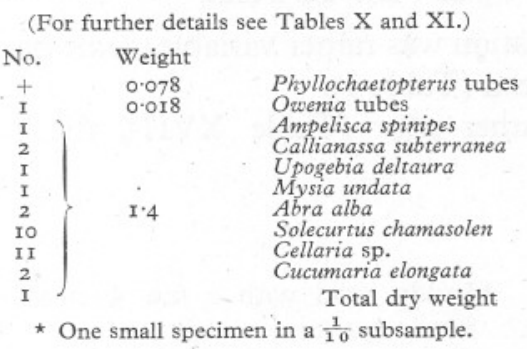

\section{Station $\mathrm{B}_{2}$}

$50^{\circ} 16^{\prime}$ N., $4^{\circ} 10^{\prime}$ W. Fine muddy sand with small stones. Depth: 48 m. I8. v. 50. Area: $0.5 \mathrm{~m} .{ }^{2}$. Sieve: $2.2 \mathrm{~mm}$. A marker float was achored close to the position of the first haul, and the total drift during five hauls was found to be about I50 yards (I37 m.).

The percentage of coarse material was high (Table I), 27\% being over $2 \mathrm{~mm}$., and there was a fairly high percentage of silt $(8.6 \%)$ which resulted in the presence of such species as Notomastus, Myxicola, Solecurtus chamasolen and Cucumaria elongata (Table XV). Two species of burrowing prawn, Callianassa subterranea and Upogebia deltaura, were taken.

The total weight of $6.4 \mathrm{~g}$. is largely made up of two specimens of Upogebia and one large and several small Solecurtus.

\section{Station $\mathrm{B}_{3}$}

$50^{\circ} \mathrm{I}^{\prime}$ N., $4^{\circ} \mathrm{IO}^{\prime}$ W. Muddy sand. Depth: $53 \mathrm{~m}$. I8. v. 50 . Area: $0.5 \mathrm{~m} .^{2}$. Sieve: $\mathrm{I} \cdot 2 \mathrm{~mm}$.

The soil was finer and less muddy ( $4 \cdot 4 \%$ silt) than at B2 (Table I). Some of the same species occurred (Table XVI) (Abra alba, Solecurtus chamasolen), but the difference in soil is reflected in the presence of species characteristic of slightly muddy sand: Cultellus, Echinocardium and Labidoplax.

The deposit was sieved through a finer sieve than usual, and this retained a greater number of polychaete worms and small Crustacea. They appear to have little effect on the total biomass, however, the dry weight for polychaetes 
being of the same order as at similar stations where the $2.2 \mathrm{~mm}$. sieve was employed ( $\mathrm{A}_{3}, \mathrm{~A}_{4}$ and $\mathrm{B}_{2}$ ), and the weight of the small Crustacea is negligible.

The large sabellarian worm Pallasia murata contributes about a quarter to the weight of polychaetes. Much of the total dry weight is made up of large individuals-Solecurtus, Echinocardium and Labidoplax.

For stations B $4-B_{7}$ see pp. 29-36.

\section{Station $C_{\mathrm{I}}$}

$50^{\circ} 17^{\prime} \mathrm{N} ., 4^{\circ} 5^{\prime} \mathrm{W}$. Fine gravel of shell fragments and small stones. Depth: $37 \mathrm{~m}$. 7. xi. 50. Area: $0.5 \mathrm{~m} .{ }^{2}$. Sieve $2.2 \mathrm{~mm}$.

The soil at this station was rather variable, some hauls being rather muddy and others quite clean (Table I).

The fauna is rather poor (Table XVII), the total dry weight being only $\mathrm{I} \cdot 3 \mathrm{~g}$.

\section{Station $\mathrm{C}_{2}$}

$50^{\circ} 15^{\prime} \mathrm{N} ., 4^{\circ} 5^{\prime} \mathrm{W}$. Muddy sand with a few stones (Table I). Depth: $46 \mathrm{~m}$. 7. xi. 50. Area: $0.5 \mathrm{~m} .^{2}$. Sieve: $2.2 \mathrm{~mm}$.

The fauna (Table XVIII) is typical of muddy sand, but is rather poor. The occurrence of Lepton squamosum, a small lamellibranch commensal with Upogebia, is of interest.

Apart from Labidoplax, there are no individuals of any size, and the total dry weight is only $2.5 \mathrm{~g}$.

\section{Station $\mathrm{C}_{3}$}

$50^{\circ} 13^{\prime}$ N., $4^{\circ} 5^{\prime} \mathrm{W}$. Muddy sand with a few stones (Table I). Depth: $46 \mathrm{~m}$. 7. xi. 50 . Area: $0.5 \mathrm{~m}^{2}{ }^{2}$. Sieve: $2 \cdot 2 \mathrm{~mm}$.

The bottom at this station is evidently rocky with pockets of sediment. A single core sample (Table II) showed no sediment overlying the rock. The fauna (Table XIX) is rather poor, except for fifteen specimens of Ophiothrix, which were all or nearly all taken in a single haul of the sampler.

The total dry weight, $4.5 \mathrm{~g}$., is rather below the average.

\section{Fauna of sandy grounds around the Eddystone}

At the stations so far described there is much variation in both grades of deposit and fauna, but at certain stations farther offshore, to the south and east of the Eddystone, there is a marked uniformity in grade of soil and fauna.

As already shown (pp. I4-I9), the fauna in successive hauls at B 5 does not vary greatly, being little more patchy than would be expected from a random distribution. The same uniformity extends over a much larger area, a very similar fauna being found at stations $\mathrm{A}_{6}, \mathrm{~A}_{7}, \mathrm{~B}_{4}, \mathrm{~B} 5, \mathrm{~B} 6, \mathrm{~B}_{7}, \mathrm{C}_{4}, \mathrm{C}_{5}$ and $\mathrm{C} 6$. 
TAble XVI. Station B 3 . Numbers and Weights Per $\frac{1}{2} M^{2}$

(For further details see Tables $\mathrm{X}$ and XI.)

\begin{tabular}{|c|c|c|c|c|c|}
\hline & No. & Weight & & No. & Weight \\
\hline $\begin{array}{l}\text { Hydroid } \\
\text { Aphroditidae }\end{array}$ & + & 0.13 & $\begin{array}{l}\text { Diastylis laevis } \\
\text { Ampelisca diadema }\end{array}$ & $\begin{array}{l}I \\
2\end{array}$ & \\
\hline Nephthys sp. & $(8)$ & & Ampelisca tenuicornis & 4 & 0.002 \\
\hline $\begin{array}{l}\text { Eunice harassi } \\
\text { Lumbriconereis } \mathrm{sp} .\end{array}$ & $2,8 j$ & & Maera othonis & 2 & \\
\hline Scoloplos armiger & I & & Abra alba & $\mathrm{I} j$ & 0.001 \\
\hline $\begin{array}{l}\text { Magelona cincta } \\
\text { Cirratulidae }\end{array}$ & $\frac{1}{6}$ & I.4 & Solecurtus chamasolen & 3. & $2 \cdot 4$ \\
\hline $\begin{array}{l}\text { Cirratulidae } \\
\text { Ammotrypane aulogaster }\end{array}$ & $\begin{array}{l}6 \\
\mathbf{I}\end{array}$ & & $\begin{array}{l}\text { Cultellus pellucidus " } \\
\text { Cellaria sp. }\end{array}$ & $2 j$ & $\begin{array}{l}0.003 \\
0.51\end{array}$ \\
\hline $\begin{array}{l}\text { Ammotrypane aulogaster } \\
\text { Pallasia murata }\end{array}$ & I & & $\begin{array}{l}\text { Cellaria sp. } \\
\text { Polyzoa indet. }\end{array}$ & + & $\begin{array}{l}0.51 \\
0.009\end{array}$ \\
\hline Polychaeta and Nemertinea indet. & (40) & & Acrocnida brachiata & I & 0.067 \\
\hline Phascolion strombi & 2 & & Echinocardium cordatum & 2 & 0.57 \\
\hline Chaetopterus tube & I & $\cdots$ & Thyone raphanus & I & 0.14 \\
\hline Phyllochaetopterus tubes & + & . & Labidoplax digitata & $\mathbf{I}$ & 0.48 \\
\hline alpellum scalpe & $3 i$ & 0.007 & Total dry weight & & $5 \cdot 7$ \\
\hline
\end{tabular}

Table XVII. Station Ci. Numbers and Weights PeR $\frac{1}{2}$ M. ${ }^{2}$

(For further details see Tables $\mathrm{X}$ and XI.)

Nephthys sp.

Glycera sp.

Hyalinoecia bilineata

Nerine sp.

Polychaeta indet.

Ampelisca spinipes

Maera othonis

Weight

$\left.\begin{array}{c}\text { No. } \\ \text { I } \\ 3 \\ \text { I9 } \\ \text { I } \\ \left.\begin{array}{c}\text { 60 } \\ 3 \\ \text { I }\end{array}\right\}\end{array}\right\} \begin{array}{cc}\text { Weight } \\ \text { Upogebia deltaura } \\ \text { Chlamys opercularis } \\ \text { Cellaria sp. } \\ \text { Echinocyamus pusillus } \\ \text { Thyone fusus }\end{array}$
* One specimen in a $\frac{1}{10}$ subsample.

No. Weight

20.16

0.49

0.004

0.071

I'3

Table XVIII. Station C2. Numbers and Weights Per $\frac{1}{2}$ M. ${ }^{2}$

(For further details see Tables $\mathrm{X}$ and XI.)

Hydroid

Edwardsia sp.

Anemone indet.

Nephthys sp.

Glycera sp.

Lumbriconereis $\mathrm{sp}$.

Cirratulidae

? Owenia sp.

Pallasia murata

Amphicteis gunneri

Polychaeta indet.

Ampelisca spinipes

Maera othonis

Weight
0.014
0.014
0.20

1.3
0.009

Weight

0.004

0.047

0.00

0.004

0.14
0.062

0.001

0.057

0.008

$0.1 \mathrm{I}$
0.48

$2 \cdot 5$

Table XiX. Station C 3 . Numbers and Weights Per $\frac{1}{2} M^{2}{ }^{2}$

(For further details see Tables $\mathrm{X}$ and XI.)

\author{
Anemone \\ Nephthys sp. \\ ?Ovenia sp. \\ Polychaeta indet. \\ Ampelisca spinipes \\ Maera othonis
}

No. Weight

\begin{tabular}{|c|c|}
\hline $\begin{array}{l}\text { I } \\
\text { I ) }\end{array}$ & $I \cdot I$ \\
\hline (4) $\}$ & 0.68 \\
\hline $\left.\begin{array}{l}I \\
I \\
2\end{array}\right\}$ & $\begin{array}{l}0.004 \\
0.088\end{array}$ \\
\hline
\end{tabular}

Processa sp.

Burrowing prawn*

Dosinia lupinus

Tellina donacina

Ophiothrix fragilis

$0.088 \quad$ Total dry weight

$\begin{array}{cl}\text { No. } & \text { Weight } \\ \text { I\} } & 0.13 \\ \text { I\} } & 0.043 \\ \text { I } & 0.032 \\ \text { I } & 2.4 \\ \text { I5 } & 0.064 \\ \text { I } & 4.5\end{array}$

* Damaged specimen of Upogebia or Callianassa. 
The fauna corresponds to that described by Ford (1923) as the EcVg (b) community, i.e. a community characterized by Echinocardium cordatum, Venus striatula (=gallina) and Abra prismatica.

The fauna taken at each station is shown in Tables XX-XXII. No one species occurs in any great numbers, but even comparatively sparse species occur regularly at most or all of the stations.

The commoner species were:

$\begin{array}{ll}\text { Edwardsia sp. } & \text { Thyasira flexuosa } \\ \text { Nephthys sp. } & \text { Phacoides borealis } \\ \text { Glycera } \mathrm{sp} . & \text { Cardium echinatum } \\ \text { Lumbriconereis sp. } & \text { Dosinia lupinus } \\ \text { Magelona papillicornis } & \text { Abra prismatica } \\ \text { M. cincta } & \text { Cultellus pellucidus } \\ \text { Pectinaria koreni } & \text { Cellaria sp. } \\ \text { Chaetopterus variopedatus } & \text { Amphiura filiformis } \\ \text { Phyllochaetopterus } \mathrm{sp} . & \text { Ophiura affinis } \\ \text { Ampelisca tenuicornis } & \text { Echinocardium cordatum } \\ \text { Nucula turgida } & \text { Labidoplax digitata }\end{array}$

Venus striatula, although a 'characteristic' species in the community described by Ford, occurs only at two out of the nine stations. Its distribution is sufficiently restricted to set the stamp on the community which it inhabits, and its continued use as a characteristic species therefore seems justified. The writer has nowhere in the Plymouth area found it in any abundance.

The occurrence of Glossobalanus sarniensis at one station is of interest-it has also been taken at B 5 (Table VI), and has been subsequently taken in a new dredge (see Forster, I953) by Mr G. R. Forster. In the Plymouth Marine Fauna (Marine Biological Association, 193I) the only Enteropneusta recorded are tornaria larvae of Balanoglossus, which are sometimes taken in planktonnettings at Plymouth. The tornaria larvae are presumably larvae of Glossobalanus from these grounds. The adult was not taken in the survey of Allen (I899), probably because the dredges used did not dig sufficiently deeply. The same species has also been taken at Salcombe by Dr D. P. Wilson (see Burdon-Jones, I953).

Details of the stations are given below:

Station $A 6$

$50^{\circ} 9^{\prime}$ N., $4^{\circ} 15^{\prime}$ W. Depth: $64 \mathrm{~m}$. Clean sand. 21. vii. 50 . Area: $0.5 \mathrm{~m} .{ }^{2}$. Sieve: $2 \cdot 2 \mathrm{~mm}$.

Station $\mathrm{A}_{7}$

$50^{\circ} 7^{\prime}$ N., $4^{\prime} 15^{\prime}$ W. Depth: $70 \mathrm{~m}$. Clean sand. 21. vii. 50. Area: $0.5 \mathrm{~m} .{ }^{2}$. Sieve: $2 \cdot 2 \mathrm{~mm}$.

\section{Station $B_{4}$}

$50^{\circ} \mathrm{I2}^{\prime} \mathrm{N} ., 4^{\circ} 10^{\prime} \mathrm{W}$. Depth: $55 \mathrm{~m}$. Slightly muddy fine sand. 18. v. 50 . Area: $0.5 \mathrm{~m} .{ }^{2}$. Sieve: $\mathrm{r} \cdot 2 \mathrm{~mm}$. 
TAble XX. Number and Weights Per $\frac{1}{2} M .{ }^{2}$

(For further details see Tables $\mathrm{X}$ and XI.)

Station $\ldots \quad \ldots \quad \ldots$

Hydroid

Edwardsia sp.

Anemone indet.

Porifera

Nemertinea

Aphroditidae

Oxydromus sp.

Hesionidae

Nereidae

Nephthys sp.

Glycera sp.

Lumbriconereis sp.

Goniada sp.

?Staurocephalus rudolphi

Scoloplos armiger

Magelona cincta

Cirratulidae

Capitellidae

Maldanidae

Pectinaria koreni

Ampharetidae

Sabellidae

Polychaeta indet.

Chaetopterus variopedatus

Phyllochaetopterus tubes

Diastylis laevis

Ampelisca tenuicornis

Bathyporeia tenuipes

Pseudoprotella phasma

Galathea sp.

Ebalia cranchi

Eulima sp.

Nucula turgida

Nucula nucleus

Thyasira flexuosa

Phacoides boreali

?Montacuta ferruginosa

?Cardium echinatum

Dosinia lupinus

Venus striatula

Abra alba

Abra prismatica

Solecurtus chamasolen

Cultellus pellucidus

Hiatella arctica

Cellaria sp.

Polyzoa indet.

Amphiura filiformis

Ophiura affinis

Echinocyamus pusillus

Echinocardium cordatum

Labidoplax digitata

Leptosynapta inhaerens

Glossobalanus sarniensis

Total dry weight

\begin{tabular}{|c|c|}
\hline & A 6 \\
\hline No. & Weight \\
\hline $\begin{array}{l}+ \\
\text { Io } j\end{array}$ & $<0.001$ \\
\hline .. & \\
\hline .. & $\cdots$ \\
\hline I ] & \\
\hline . & \\
\hline$\cdots$ & \\
\hline$\cdots$ & \\
\hline I & \\
\hline * & \\
\hline 5 & \\
\hline $\begin{array}{l}\cdots \\
\cdots\end{array}$ & 0.42 \\
\hline$\ddot{3}$ & \\
\hline $\begin{array}{l}3 \\
\ldots\end{array}$ & \\
\hline$\cdots$ & \\
\hline I & \\
\hline . & \\
\hline$\ddot{I}$ & \\
\hline (4) & \\
\hline$\ddot{I}$ & $\because$ \\
\hline 1 & $\because$ \\
\hline .. & .. \\
\hline .. & $\ldots$ \\
\hline .. & $\ldots$ \\
\hline . & . \\
\hline . & . \\
\hline $\mathrm{I}, 2 j$ & 0.032 \\
\hline$\ddot{3}$ & 0.018 \\
\hline $\begin{array}{l}3 \\
1\end{array}$ & $\begin{array}{l}0.018 \\
0.061\end{array}$ \\
\hline$\ddot{i} j$ & $0.00 I$ \\
\hline $\mathrm{Ij} j$ & 0.001 \\
\hline $\mathrm{I}, \mathrm{I} j$ & 0.051 \\
\hline$\ddot{I} j$ & 0.001 \\
\hline $7, \ddot{1}_{3 j}$ & 0.30 \\
\hline .. & $\ldots$ \\
\hline .. & .. \\
\hline . & .. \\
\hline 2 & 0.012 \\
\hline 3 & 0.005 \\
\hline I & $0 . \ddot{21}$ \\
\hline I & 0.48 \\
\hline$\because$ & $\ldots$ \\
\hline I & 0.55 \\
\hline
\end{tabular}

$2 \cdot 3$
$\mathrm{A}_{7}$

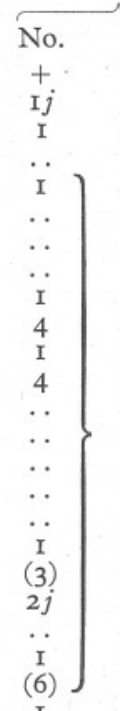

I 3

Weight

0.19

0.024

0.12

.

\begin{tabular}{|c|c|}
\hline \multicolumn{2}{|c|}{$\mathrm{B}_{4}$} \\
\hline No. & Weight \\
\hline & $\begin{array}{l}0.36 \\
0.014\end{array}$ \\
\hline I. & 0.18 \\
\hline $\mathrm{I} j$ & $<0.001$ \\
\hline
\end{tabular}

$I \cdot 3$

0.50

$\cdots$

$\cdots$

0.001

0.25

..

0.025

0.065

0.065
0.086

0.003

0.006

$\cdots$

0.022

0.022

0.058

0.042

0.002

..

0.003

0.003

$0.4 \mathrm{I}$

0.48

0.48

$3 \cdot 6$

* Empty tubes.

JOURN. MAR. BIOL. ASSOC. vol. XXXII, I953 
TAble XXI. Numbers and Weights Per $\frac{1}{2} M .^{2}$

(For further details see Tables X and XI.)

\begin{tabular}{|c|c|c|c|c|c|c|}
\hline . $\quad \ldots$ & & 5 & & 36 & & 7 \\
\hline & No. & Weight & No. & Weight & No. & Weight \\
\hline Hydroid & + & 0.026 & + & 0.92 & + & 0.45 \\
\hline $\begin{array}{l}\text { Edwardsia sp. } \\
\text { Cerianthus lloydi }\end{array}$ & $7 j$ & 0.097 & $9 j$ & $0 \cdot 13$ & $3 j$ & 0.042 \\
\hline Anemone indet. & I & 0.015 & $\ddot{j}$ & $\ddot{0}$ & $\cdots$ & $\cdots$ \\
\hline Nemertinea & $\ddot{2}$ & $\cdots$ & $\begin{array}{c}1] \\
I\end{array}$ & 0.007 & $\ddot{2}$ & $\cdots$ \\
\hline Sigalion mathildae & .. & & I & & .. & \\
\hline $\begin{array}{l}\text { Aphroditidae indet. } \\
\text { Phvllodoce } \mathrm{sp} \text {. }\end{array}$ & I & & 2. & & . & \\
\hline $\begin{array}{l}\text { Phyllodoce sp. } \\
\text { Nereidae }\end{array}$ & $\cdots$ & & $2 j$ & & .. & \\
\hline Nephthys sp. & $\ddot{3}$ & & I & & $\ddot{3}$ & \\
\hline Glycera sp. & I & & $\begin{array}{l}3 \\
\ldots\end{array}$ & & $\begin{array}{l}3 \\
1\end{array}$ & \\
\hline $\begin{array}{l}\text { Eunice harassi } \\
\text { Lumbriconereis sn }\end{array}$ & .. & & I & & .. & \\
\hline $\begin{array}{l}\text { Lumbriconereis sp. } \\
\text { Magelona papillicornis }\end{array}$ & II & $\mathrm{I} \cdot 3$ & 8 & $2 \cdot 0$ & 2 & 0.46 \\
\hline $\begin{array}{l}\text { Magelona papillicornis } \\
\text { Magelona cincta }\end{array}$ & $\ddot{2}$ & & $\ddot{2}$ & & I & \\
\hline Capitellidae & 5 & & I & & $\begin{array}{l}\cdots \\
\cdots\end{array}$ & \\
\hline Maldanidae & (5) & & 2 & & $\ddot{I}$ & \\
\hline Owenia sp. & $\mathrm{I} j$ & & . & & & \\
\hline $\begin{array}{l}\text { Pectinaria koreni } \\
\text { Terebellidae }\end{array}$ & $\because$ & & I & & tI & \\
\hline Polychaeta indet. & $\ddot{5}$ & & $\begin{array}{l}3 \\
9\end{array}$ & & $\ddot{3}$ & \\
\hline Chaetopterus variopedatus & $\mathrm{I}, \mathrm{I} j$ & $1 \cdot 2$ & 2 & $2 \cdot 3$ & $\cdots$ & $\cdots$ \\
\hline Phyllochaetopterus tubes & + & & + & $\cdots$ & + & . \\
\hline Scalpellum scalpellum & $\mathrm{I} j$ & 0.006 & $\mathrm{I} j$ & 0.001 & $\cdots$ & . \\
\hline $\begin{array}{l}\text { Ampelisca tenuicornis } \\
\text { Galathea sp. }\end{array}$ & 5 & 0.002 & I. & $<0.001$ & . & .. \\
\hline $\begin{array}{l}\text { Galathea sp. } \\
\text { Eupagurus sp. }\end{array}$ & $\tau_{i}$ & ع & $3 j$ & 0.018 & $\cdots$ & $\cdots$ \\
\hline $\begin{array}{l}\text { Eupagurus sp. } \\
\text { Eurynome aspera }\end{array}$ & $\mathrm{I} j$ & 0.005 & $\because$ & $\cdots$ & . & . \\
\hline $\begin{array}{l}\text { Eurynome aspera } \\
\text { Nucula nucleus }\end{array}$ & $\ddot{r}$ & $\therefore$. & $\mathrm{I} j$ & 0.14 & $\cdots$ & $\cdots$ \\
\hline $\begin{array}{l}\text { Nucula nucleus } \\
\text { Nucula turgida }\end{array}$ & 3 & $\begin{array}{l}0.003 \\
0.008\end{array}$ & 2 & 0.028 & $\ddot{I}$ & 0.003 \\
\hline $\begin{array}{l}\text { Nucula turgida } \\
\text { Chlamys sp. }\end{array}$ & .. & 0.008 & 2 & 0.010 & I. & 0.003 \\
\hline $\begin{array}{l}\text { Chlamys sp. } \\
\text { Thyasira flexuosa }\end{array}$ & $\because$ & $\begin{array}{l}. \\
\ldots\end{array}$ & $\ddot{2}$ & ․ㅛ8 & $3 j$ & $\begin{array}{l}0.004 \\
0.022\end{array}$ \\
\hline $\begin{array}{l}\text { Thyasira flexuosa } \\
\text { Phacoides borealis }\end{array}$ & $3, \mathrm{I} j$ & $0 \cdot 16$ & 2 & 0.018 & 3 & $\begin{array}{l}0.022 \\
0.18\end{array}$ \\
\hline $\begin{array}{l}\text { Phacoides borealis } \\
\text { Montacuta ferruginosa }\end{array}$ & .. & .. & $\begin{array}{l}\cdots \\
\ldots\end{array}$ & $\cdots$ & 3 & $0 \cdot 18$ \\
\hline $\begin{array}{l}\text { Montacuta ferruginosa } \\
\text { Cyprina islandica }\end{array}$ & $\mathrm{I} j$ & 0.003 & $\cdots$ & . & I & 0.004 \\
\hline $\begin{array}{l}\text { Cyprina islandica } \\
\text { Cardium echinatum }\end{array}$ & I & 3.6 & . & $\cdots$ & I & $7 \cdot 6$ \\
\hline $\begin{array}{l}\text { Cardium echinatum } \\
\text { ?Cardium echinatum }\end{array}$ & $4 j$ & $\begin{array}{l}3.0 \\
0.018\end{array}$ & $\cdots$ & $\cdots$ & $\cdots$ & .. \\
\hline $\begin{array}{l}\text { ?Cardium echinatum } \\
\text { Dosinia lupinus }\end{array}$ & & & . & $\cdots$ & $3 j$ & 0.008 \\
\hline $\begin{array}{l}\text { Dosinia lupinus } \\
\text { Tellina donacina }\end{array}$ & 1 & 0.094 & I. & 0.42 & I & 0.46 \\
\hline $\begin{array}{l}\text { Tellina donacina } \\
\text { ?Abra prismatica }\end{array}$ & $\begin{array}{l}\cdots \\
\cdots\end{array}$ & $\cdots$ & $\mathrm{I} j$ & 0.003 & $\cdots$ & $\cdots$ \\
\hline 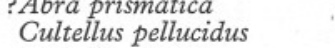 & $\ddot{\mathrm{I}} \overline{7 j}$ & 0.025 & $5^{2}$ & 0.022 & $\because$ & . \\
\hline Hiatella arctica & .. & $\begin{array}{c}0.25 \\
\ldots\end{array}$ & $\begin{array}{c}5,73 \\
\ldots\end{array}$ & $\begin{array}{c}0.16 \\
\ldots\end{array}$ & $\stackrel{5}{\mathrm{I} j}$ & $\begin{array}{l}0.019 \\
0.003\end{array}$ \\
\hline Cochlodesma praetenue & . & . & I & 0.017 & $\mathrm{I} j$ & 0.003 \\
\hline Cellaria sp. & + & 0.012 & + & 0.037 & .. & $\ldots$ \\
\hline Polyzoa indet. & + & 0.024 & + & 0.025 & .. & $\cdots$ \\
\hline Ophiothrix fragilis. & I & 0.003 & 2 & 0.24 & .. & $\cdots$ \\
\hline Amphiura filiformis & 3 & 0.004 & .. & $\cdots$ & $\cdots$ & . \\
\hline Ophiura affinis & I & 0.002 & I & 0.002 & 3 & 0.002 \\
\hline Echinocyamus pusillus & . & $\cdots$ & . & . & I & 0.001 \\
\hline Echinocardium cordatum & 2 & 0.55 & $\cdots$ & . & 2 & 0.55 \\
\hline Cucumaria lactea & .. & .. & 5 & 0.070 & .. & .. \\
\hline Labidoplax digitata & 2 & 0.97 & I & 0.48 & 2 & 0.97 \\
\hline Total dry weight & & $8 \cdot I$ & & $7 \cdot 0$ & & I0.8 \\
\hline
\end{tabular}

* Small specimens, which could not be identified with certainty.

† Identity doubtful. 
TAble XXII. Numbers and WeightS PeR $\frac{1}{2}$ M. ${ }^{2}$

(For further details see Tables $\mathrm{X}$ and XI.)

Hydroid

Edwardsia sp.

Cerianthus lloydi

Anemone indet.

Nemertinea

Sthenelais limicola

Aphroditidae

Nereis $\mathrm{sp}$.

Nephthys sp.

Glycera sp.

Lumbriconereis $\mathrm{sp}$.

Nerine sp.

Magelona papillicornis

Magelona cincta

Maldanidae

?Owenia sp.

Pectinaria koremi

Polychaeta indet.

Chaetopterus variopedatus

Phyllochaetopterus tubes

Scalpellum scalpellum

Leucothoë sp. *

Aorid

Pseudoprotella phasma

?Porcellana longicornis

Corystes cassivelaunus

Cylichna sp.

Nucula turgida

Thyasira flexuosa

Phacoides borealis

Cardium echinatum

?Cardium echinatum $\dagger$

Dosinia lupinus

Venus striatula

Abra alba

Abra prismatica

Gari fervensis

Solecurtus chamasolen

Cultellus pellucidus

Ensis ensis

?Thracia pubescens

Cellaria sp.

Ophiothrix fragilis

Acrocnida brachiato

Ophiura affinis

Echinocyamus pusillus

Echinocardium cordatum

Echinocardium sp. $\dagger$

Labidoplax digitata

Ascidiella aspersa

Aphya pellucida

Total dry weight

\begin{tabular}{|c|c|}
\hline & 4 \\
\hline No. & Weight \\
\hline$\ddot{i} j$ & $\ddot{0.014}$ \\
\hline$\ddot{I}$ & $\ddot{0} 6$ \\
\hline $\begin{array}{l}\mathrm{I} \\
. .\end{array}$ & $\begin{array}{c}0.36 \\
\ldots\end{array}$ \\
\hline I & \\
\hline 2 & \\
\hline$\ddot{2}$ & \\
\hline 3 & \\
\hline 3 & $\mathrm{I} \cdot 2$ \\
\hline$\because$. & \\
\hline I & \\
\hline$\cdots$ & \\
\hline$\ddot{2} j$ & \\
\hline $\begin{array}{l}3 \\
\ldots\end{array}$ & \\
\hline$\cdots$ & $\cdots$ \\
\hline$\cdots$ & $\ldots$ \\
\hline . & . \\
\hline$\cdots$ & $\cdots$ \\
\hline$\cdots$ & . \\
\hline$\ddot{I}$ & 1.0 \\
\hline I & 0.006 \\
\hline 4 & 0.047 \\
\hline 8 & 0.043 \\
\hline$\cdots$ & $\cdots$ \\
\hline$\cdots$ & $\cdots$ \\
\hline$\ddot{i} j$ & 0.013 \\
\hline I $j$ & 0.001 \\
\hline $\begin{array}{c}\mathrm{I} \\
\mathrm{I} j\end{array}$ & O.0II \\
\hline & $\because$ \\
\hline I & 0.47 \\
\hline I4 & O.II \\
\hline I & 0.73 \\
\hline$\ddot{+}$ & ०.00I \\
\hline . & .. \\
\hline$\ddot{2}$ & ०.00I \\
\hline$\ddot{3} i$ & $\ddot{1} \cdot \overrightarrow{2}$ \\
\hline .. & . \\
\hline .. & .. \\
\hline .. & .. \\
\hline$\cdots$ & $\cdots$ \\
\hline
\end{tabular}

$5 \cdot 7$
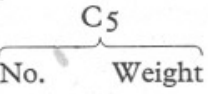

0.040

0.019

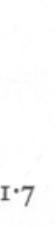

I· 7

$2 \cdot 0$

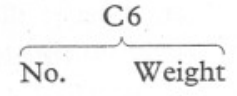

0.66

0.042

.

$2 \cdot 3$

0.083

0.001

0.015

0.042

$0.05 \mathrm{I}$

0.044

0.025

0.050

0.010

$4 \cdot 0$

0.010

.

0.017

0.003

..

..

O. I I

.

‥ำ

0.010

0.021

0.002

..

0.57

0.48

.

$7 \cdot 2$

* See p. 25.

† Small specimens, which could not be identified with certainty.

\# The weight of this fish is not included.

A query (?) before the number of individuals indicates uncertain identity. 
Station $B 5$

$50^{\circ} \mathrm{IO}^{\prime}$ N., $4^{\circ}$ Io' $^{\prime}$ W. Depth: $60 \mathrm{~m}$. Clean sand. 3. vii. 50 . Area: $0.5 \mathrm{~m} .^{?}$. Sieve: $2 \cdot 2 \mathrm{~mm}$.

N.B. This is distinct from the series of hauls made at this station on $5 . x i i .50$, described on pp. 14-19.

Station $B 6$

$50^{\circ} 8^{\prime}$ N., $4^{\circ}$ Io' $^{\prime}$ W. Depth: $62 \mathrm{~m}$. Clean sand. 3. vii. 50 . Area: $0.5 \mathrm{~m} .{ }^{2}$. Sieve: $2.2 \mathrm{~mm}$.

\section{Station $\mathrm{B}_{7}$}

$50^{\circ} 6^{\prime}$ N., $4^{\circ}$ Io' $^{\prime}$ W. Depth: $68 \mathrm{~m}$. Clean sand. 3. vii. 50 . Area: $0.5 \mathrm{~m} .^{2}$. Sieve: $2 \cdot 2 \mathrm{~mm}$.

\section{Station $\mathrm{C}_{4}$}

$50^{\circ} \mathrm{II}^{\prime}$ N., $4^{\circ} 5^{\prime}$ W. Depth: $57 \mathrm{~m}$. Clean sand. 27. vii. 50 . Area: $0.5 \mathrm{~m} .^{2}$. Sieve: $2 \cdot 2 \mathrm{~mm}$.

N.B. This is distinct from the hauls made at this station on $7 . x i .50$, described on pp. $2 \mathrm{I}-22$.

Station $C_{5}$

$50^{\circ} 9^{\prime}$ N., $4^{\circ} 5^{\prime}$ W. Depth: 62 m. 27. vii. 50 . Area: 0.5 m. ${ }^{2}$. Sieve: $2.2 \mathrm{~mm}$.

Station $\mathrm{C6}$

$50^{\circ} 7^{\prime}$ N., $4^{\circ} 5^{\prime}$ W. Depth: $66 \mathrm{~m}$. 27. vii. 50. Area: $0.5 \mathrm{~m} .{ }^{2}$. Sieve: $2 \cdot 2 \mathrm{~mm}$.

The total dry weight on these grounds ranges from $2 \cdot 3 \mathrm{~g}$. (A6) to $10.8 \mathrm{~g}$. (B 7) per $\frac{1}{2} \mathrm{~m} .^{2}$. The mean figure for the nine stations is $6 \cdot 7 \mathrm{~g}$. The great variability in the catch from one station to the next is due to the occurrence of large lamellibranchs, Cyprina and Cardium echinatum in particular, which are present in some samples and not in others.

\section{Dry weight at $B_{5}$}

The $0.5 \mathrm{~m} .^{2}$ sample of 3 July I950, from a $2.2 \mathrm{~mm}$. sieve, gave a figure of $8 \cdot \mathrm{I} \mathrm{g} \cdot / \frac{1}{2} \mathrm{~m} .{ }^{2}$. The $2 \mathrm{~m} .{ }^{2}$ sample of 5 December 1950 , from a I $2 \mathrm{~mm}$. sieve, gave II 6 g. $/ \frac{1}{2} \mathrm{~m}^{2}$, as set out in Table XXIII. The difference is partly accounted for by the use of a different sieve, which resulted in a doubling of the weight of Polychaeta (other than Chaetopterus) taken with the finer meshed sieve; but for other groups the differences were not so great. Since the total weight was made up mostly of a few large individuals, the discrepancy is partly attributable also to sampling errors.

If we ignore the weights of the Polychaeta (other than Chaetopterus), and of large specimens of Cardium echinatum and Cyprina islandica, the totals become:

$$
\begin{aligned}
& \frac{1}{2} \mathrm{~m}^{2} \text { sample of } 3 . \text { vii. } 50: 3 \cdot 2 \mathrm{~g} \cdot / \frac{1}{2} \mathrm{~m}^{2} \text {, } \\
& 2 \mathrm{~m} .^{2} \text { sample of } / 5 . \text { xii. } 50: 3 \cdot 3 \mathrm{~g} \cdot / \frac{1}{2} \mathrm{~m} .^{2} \text {, }
\end{aligned}
$$

which is a reasonably good agreement. 
Table XXIII. Station B5, 5 December i950. Dry Weights Per 2 M. $^{2}$

For some species the weights obtained for each series of ten samples is also given (samples: I-IO/II-20/2I-30/3I-40.)

Assumed weights are in italics.

\begin{tabular}{|c|c|c|}
\hline Hydroid & & 0.42 \\
\hline Virgularia mirabilis & & 0.004 \\
\hline Cerianthus lloydi & & 0.047 \\
\hline Edwardsia sp. & & 0.25 \\
\hline Chaetopterus variopedatus & $-\mid 1 \cdot 1 / 1 \cdot 1 / 1 \cdot 1$ & $3 \cdot 3$ \\
\hline $\begin{array}{l}\text { Other Polychaeta, Gephyrea } \\
\text { Amphipoda }\end{array}$ & $I \cdot 8 / 2 \cdot I / 3 \cdot 6 / I \cdot 9$ & $\begin{array}{l}9 \cdot 4 \\
0 \cdot 012\end{array}$ \\
\hline Other Crustacea & & 0.37 \\
\hline Acteon tornatilis & $0.001 / 0.001 /-/-$ & 0.002 \\
\hline Cylichna cylindracea & $-10.001 /-10.001$ & 0.002 \\
\hline Nucula nucleus & $0.001 /-1-1-$ & 0.001 \\
\hline Nucula turgida & $0.013 / 0.006 / 0.008 / 0.037$ & 0.064 \\
\hline Musculus marmoratus & $-10.001 /-1-$ & 0.001 \\
\hline Chlamys sp.* & $-10.006 /-10 . \mathrm{II}$ & 0.116 \\
\hline Thyasira flexuosa & $0.019 / 0.007 / 0.011 / 0.008$ & 0.045 \\
\hline Phacoides borealis $\star$ & $0.39 / 0.087 / 0.26 / 0.26$ & 0.997 \\
\hline Montacuta ferruginosa & $0.007 /-10.006 /-$ & 0.013 \\
\hline Cyprina islandica & $9 \cdot 7 /-19 \cdot 7 /-$ & $19 \cdot 4$ \\
\hline Cardium echinatum & $0.015 /-1-14.2$ & $4 \cdot 215$ \\
\hline Dosinia lupinus & $0.94 / 0.047 / 0.49 / 0.19$ & $I \cdot 667$ \\
\hline Venus ovata & $0.001 /-1-1-$ & 0.001 \\
\hline Venus striatula & $0.004 / 0 . \mathrm{II} / 0.52 /-$ & 0.634 \\
\hline Venerupis rhomboides & $0.006 / 0.007 /-1-$ & $0.0 I_{3}$ \\
\hline Abra alba & $-|-| 0.014 /-$ & O.OI4 \\
\hline Abra prismatica & $0.01 \mathrm{I} / 0.024 / 0.026 / 0.014$ & 0.075 \\
\hline Gari fervensis & $0.001 / 0.001 / 0.040 /-$ & 0.042 \\
\hline Cultellus pellucidus & $0.080 / 0.043 / 0.097 / 0$. I I & 0.330 \\
\hline Hiatella arctica & $0.006 / 0.008 /-1-$ & O.OI4 \\
\hline Cochlodesma praetenue & $0.010 /-10.003 / 0.003$ & 0.016 \\
\hline Lyonsia norwegica & $-1-10.003 /-$ & 0.003 \\
\hline Cellaria sp. & & 0.066 \\
\hline Ophiuroidea & & 0.13 \\
\hline Echinocyamus pusillus & & $<0.001$ \\
\hline Echinocardium cordatum & & $I \cdot 2$ \\
\hline Labidoplax digitata & & $1 \cdot 6$ \\
\hline Tunicata & & 0.63 \\
\hline Glossobalanus sarniensis & & $1 \cdot 1$ \\
\hline Total & & $46 \cdot 2$ \\
\hline
\end{tabular}

* The following corrections are necessary when comparing with Table VI: Phacoides borealis, 8 , not 9 , specimens in samples $\mathrm{I}-\mathrm{IO} ; 8$, not $\mathrm{IO}$, in samples $2 \mathrm{I}-30$ (when the shells were opened for weighing three were found to be empty). Chlamys sp. A single specimen, not recorded in Table VI, was found in hauls $3 \mathrm{I}-40$.

\section{Summary OF BIOMASS DATA}

For all stations, the mean dry weight of animal tissue is $\mathrm{II} \cdot 2 \mathrm{~g} . / \mathrm{m} .{ }^{2}$, which is equivalent to about $55 \mathrm{~g}$. fresh weight. While this figure is sufficient for comparative purposes, there are a number of corrections to be applied if an absolute figure is required. Apart from any errors due to the small size of the area sampled, the following sources of error are present:

(i) Animals missed by the instrument, either because they live too deeply in the deposit, or are able to evade the sampler. Since the magnitude of the error is unknown, no correction can be applied.

(ii) Loss of small animals through the sieve. It is believed that the use of 
a $\mathrm{I} \cdot \mathrm{O}$ or $\mathrm{I} \cdot 2 \mathrm{~mm}$. sieve, the usual mesh in such investigations, would increase the total dry weight taken by about 10\% (p. 22).

(iii) Weight of sand in the guts, estimated as $5 \%$ of the alcohol weight (p. 24). Taking $27 \cdot 72$ as the mean percentage dry weight relative to the alcohol weight (p. 23), the corrected percentage becomes 22.72 , i.e. the dry weight figure should be reduced by about $18 \%$.

Applying corrections for sieving errors and gut content, a figure of about Io g. $/ \mathrm{m}^{2}$ dry weight is reached.

As already emphasized, much of the total dry weight is made up of large individuals, having a relatively low metabolic rate, and therefore of less importance from the aspect of productivity than their weight would suggest. The percentage of individuals, each weighing over $0.2 \mathrm{~g}$. dry (=c. I g. fresh weight), is given below:

\begin{tabular}{|c|c|c|c|}
\hline Station & $\begin{array}{l}\text { Percentage } \\
\text { over } 0.2 \mathrm{~g} \text {. }\end{array}$ & Station & $\begin{array}{l}\text { Percentage } \\
\text { over } 0.2 \mathrm{~g} \text {. }\end{array}$ \\
\hline $\mathrm{A}_{\mathrm{I}}$ & 0 & $\mathrm{~B}_{5}$ & $77 \cdot 6$ \\
\hline $\mathrm{A} 2$ & $76 \cdot 9$ & B6 & 45.4 \\
\hline $\mathrm{A}_{3}$ & $22 \cdot 2$ & B 7 & 88.8 \\
\hline $\mathrm{A}_{4}$ & 58.5 & $\mathrm{C}_{I}$ & $37 \cdot 4$ \\
\hline A5 & $90 \cdot \mathrm{I}$ & $\mathrm{C}_{2}$ & 20.0 \\
\hline A6 & $53 \cdot 2$ & $\mathrm{C}_{3}$ & $23 \cdot 6$ \\
\hline A 7 & 46.0 & $\mathrm{C}_{4}$ & $74 \cdot 3$ \\
\hline $\mathrm{BI}$ & 100 & $\mathrm{C}_{5}$ & 70.1 \\
\hline $\mathrm{B}_{2}$ & $72 \cdot 6$ & C6 & 62.8 \\
\hline $\mathrm{B}_{3}$ & $60 \cdot 2$ & & \\
\hline $\mathrm{B}_{4}$ & 50.0 & Total & $64 \cdot 4$ \\
\hline
\end{tabular}

An analysis has been made of the percentages of the total weight made up by the different groups of the animal kingdom, both for all twenty stations and for the nine stations on the sandy grounds outside the Eddystone. These show the preponderance of Polychaeta, Lamellibranchia and Echinodermata; the only other groups occurring in significant quantities being Coelenterata and Malacostraca (the percentages are shown graphically in Fig. 7):
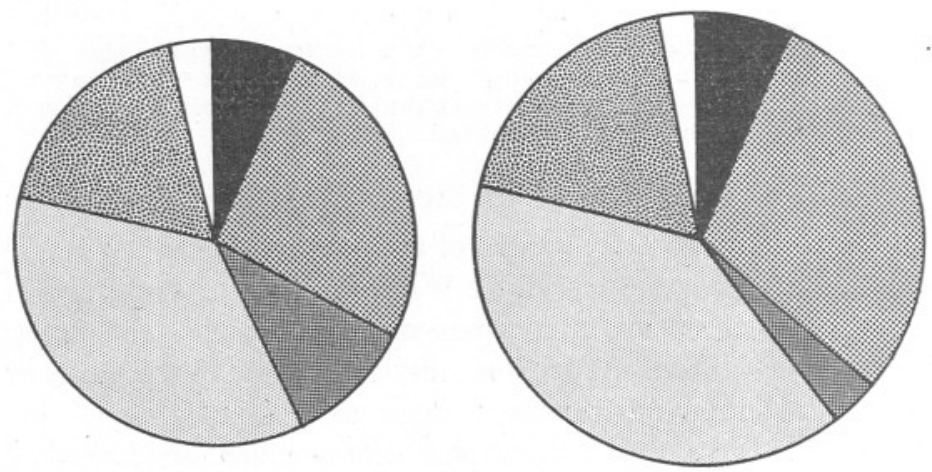

Fig. 7. Percentage composition by weight of the fauna. Left: all stations in the 1950 survey; right: stations on the Eddystone sandy grounds only. The area of the circles is proportional to the total biomass. 태, Coelenterata;

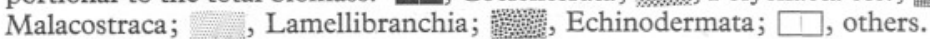




$\begin{array}{lcc} & \text { All stations } & \begin{array}{c}\text { Eddystone } \\ \text { sandy grounds }\end{array} \\ \text { Coelenterata } & 7.00 & 6.84 \\ \text { Polychaeta and Nemertinea } & 25.79 & 29.49 \\ \text { Eumalacostraca } & 0.16 & 0.16 \\ \text { Malacostraca } & 10.35 & 3.38 \\ \text { Gastropoda } & 0.02 & 0.01 \\ \text { Lamellibranchia } & 35.46 & 39.10 \\ \text { Polyzoa } & 2.46 & \mathrm{I} \cdot 76 \\ \text { Echinodermata } & 17.88 & 18.33 \\ \text { Protochordata } & 0.88 & 0.93\end{array}$

The only major difference is in the low figure for Malacostraca on the Eddystone grounds, attributable to the scarcity of the burrowing prawns Upogebia and Callianassa.

\section{Changes in the Bottom Fauna}

\section{Allen's survey}

Allen's (I899) survey of the bottom fauna in the neighbourhood of the Eddystone was largely based on dredge hauls. His grounds I-III and VI correspond with the Eddystone sandy grounds described in this paper. His species lists are mainly made up of members of the epi-fauna, among which hydroids figure prominently, but there is no reason to suppose that any major qualitative changes have occurred over the past fifty years.

One species, the scaphopod mollusc Dentalium entalis, is now conspicuous by its absence. Allen records this species alive from all fine sand grounds, with the exception of haul I04 on ground II, where the absence of this species was noteworthy. In the past few years no living Dentalium has been taken at Plymouth, although empty shells are very common. Specimens have recently been taken, however, in dredge and grab hauls in the mouth of the Channel, south of Land's End.

\section{Ford's survey}

The survey by Ford (I923) provides data on the density of the bottom fauna in 1922-23 for many positions off Plymouth. Any comparison with the I950 results is complicated, however, by: (i) Ford used the $\frac{1}{10} \mathrm{~m} .{ }^{2}$ Petersen grab, which has been shown (pp. II-I2) to sample less efficiently than the scoopsampler used in the I950 survey. (ii) The patchy nature of the inshore grounds and the fact that the same positions were not revisited in 1950 makes any exact comparison impossible. Ford did not sample the sandy grounds outside the Eddystone. (iii) Any comparison can only be in terms of numbers of animals, irrespective of their size or weight, since Ford gives no such data. (iv) Ford used the finest sieve in the Challenger series, which has openings of about I.2 mm., whereas a $2 \cdot 2 \mathrm{~mm}$. sieve was used in I950. (v) The samples described by Ford were selected to illustrate the different types of community to be found, and some of the less productive samples were omitted. For the same reason stations tend to be aggregated in the richer areas. 
Mr Ford has kindly lent me his original notes, which include records of samples not published in his paper; all his stations within the area covered in I950 are used in the comparisons which follow. To eliminate any bias due to aggregation of Ford's stations, those from certain areas have been averaged and scaled down so as to contribute only $\frac{1}{2} \mathrm{~m} .{ }^{2}$ to the total. The samples, positions of which are shown in Fig. I (p. 4), are summated thus.

$\begin{array}{lcc}\text { Whitsand Bay } & \begin{array}{c}\text { Sampled } \\ \left(\mathrm{m} .{ }^{2}\right)\end{array} & \begin{array}{c}\text { Reduced to } \\ \left(\mathrm{m} . .^{2}\right)\end{array} \\ \text { Rame mud } & 4.8 & 0.5 \\ \text { Eddystone } & 3 \cdot 7 & 0.5 \\ \text { Mewstone } & 3 \cdot \mathrm{I} & 0.5 \\ \text { Other samples } & 2 \cdot \mathrm{I} & 0.5 \\ \quad & 6 \cdot 2 & 6 \cdot 2 \\ \text { Total } & & 8 \cdot 2\end{array}$

For comparison, the following I950 stations have been taken: A I, A 2, A 3 , $\mathrm{A}_{4}, \mathrm{~A}_{5}, \mathrm{~B}_{1}, \mathrm{~B}_{2}, \mathrm{~B}_{3}, \mathrm{~B}_{4}, \mathrm{~B}_{5}, \mathrm{C}_{1}, \mathrm{C}_{2}, \mathrm{C}_{3}, \mathrm{C}_{4}$. The total area is $7 \mathrm{~m}^{2}$, and figures for both surveys have been converted to densities per ro $\mathrm{m}^{2}$. (Two small divergencies in the 1950 survey have been ignored-these are the use of a $\mathrm{I}_{2} \mathrm{~mm}$. sieve at $\mathrm{B}_{3}$ and $\mathrm{B}_{4}$ and the sampling of $0.6 \mathrm{~m}^{2}$ instead of $0.5 \mathrm{~m}^{2}$ at $\mathrm{A}_{3}$.)

A comparison of the lamellibranch faunas is given in Table XXIV. Before considering this in detail, allowance must be made for the different sieves used. The $2.2 \mathrm{~mm}$. sieve used in I950 had square apertures of c. $3 \mathrm{~mm}$. diagonal, so that a shell having a breadth of less than $3 \mathrm{~mm}$. may pass through end-on.

It is difficult to estimate the percentage losses due to use of the coarser sieve. Station B 5 was sampled on two occasions: on the first (Table XXI) an area of $0.5 \mathrm{~m}^{2}$ was sieved through the $2.2 \mathrm{~mm}$. sieve, on the second (Table VI) an area of $2 \mathrm{~m} .^{2}$ was sieved through a $\mathrm{I} \cdot 2 \mathrm{~mm}$. mesh. The results indicate that the coarser sieve retained over half $(57.5 \%)$ of the numbers retained by the $\mathrm{I} \cdot 2 \mathrm{~mm}$. sieve. The figure for the razor-shell, Cultellus, is $80 \%$.

At $\mathrm{C}_{4}$ (Table VIII) the sample of 7 November 1950 was passed through first the $2.2 \mathrm{~mm}$. and then the I.2 mm. sieve. Only $32 \%$ of the total was found on the coarser sieve.

If the samples from A I, where a $2 \cdot 2 \mathrm{~mm}$. mesh was used, and from the nearby station in Whitsand Bay ( $\mathrm{I} \cdot 2 \mathrm{~mm}$. mesh used) are compared, a figure of $5 \mathrm{I} \%$ is obtained as the percentage retained by the coarser sieve.

It is not claimed that any of the above comparisons have any great validity, but if we take $50 \%$ as the correction to be made, no great error should result.

Ford (I925) gives some data on the growth of lamellibranchs, from which it follows that spat of the larger species very soon grow sufficiently large to be retained by a $2.2 \mathrm{~mm}$. mesh. Abra alba, for which species most data is available, has a shell breadth 
equal to $c .72 \%$ of its length. Individuals up to about $4 \mathrm{~mm}$. would therefore pass a sieve of this mesh. Of a total of $739 \mathrm{I}$ individuals measured from samples taken through the year in Bigbury Bay (east of Plymouth), only $9.16 \%$ were in the $4 \mathrm{~mm}$. length group or below. The percentage varied from nil to $90 \%$ according to the season.

Spisula elliptica spat grew from 3.44 to $6.18 \mathrm{~mm}$. length in 20 days in July and Lutraria lutraria increased from 3 to $\mathrm{I} 2 \mathrm{~mm}$. in 6 weeks. Individuals of Cultellus spatted in June 1922, grew to $15-20 \mathrm{~mm}$. in length by the autumn of the same year. Since the shell breadth of Cultellus is some $20 \%$ of its length, it follows that individuals up to $15 \mathrm{~mm}$. length might pass the sieve. But an analysis of the lengths of shells taken in the $2.2 \mathrm{~mm}$. sieve in 1950 shows that many below this length were retained. Of II6 specimens taken $29(25 \%)$ were $15 \mathrm{~mm}$. or over, $74(63.8 \%)$ were between IO and $15 \mathrm{~mm}$., and $\mathrm{I}_{3}(\mathrm{II} \cdot 2 \%)$ were less than $\mathrm{IO} \mathrm{mm}$. There is no reason to suppose, therefore, that losses of Cultellus were exceptionally high.

Where small species such as Nucula and Corbula are concerned losses through the coarse sieve may be considerable.

The sampling capabilities of the Petersen grab and the scoop-sampler vary with the nature of the sediment, and therefore the relative degree of penetration by the two samplers and also with the depth of individuals in the sediment. On the whole, older individuals (particularly of lamellibranchs) tend to be deeper down in the sediment. Data given in Table III, also in Holme (I949), suggest that the Petersen grab takes half or less than half as many individuals per unit area as does the scoop-sampler.

It therefore follows that two corrections must be applied to the data in Table II. The I950 results must be doubled to allow for sieving error and the I922-23 results doubled to allow for individuals missed by the Petersen grab. The ratios of the two sets of sample can therefore be taken direct from the table.

Of the differences in total population numbers shown in Table XXIV, the greater part is due to two species, Abra alba and Cultellus.

Taking the number of individuals of Abra which would have been lost had the coarse sieve been used as $9 \%$, the population decline over the period is seen to be to $3.6 \%$ of its original value. There is reason to believe that $A b r a$ was exceptionally abundant at the time of Ford's survey; indeed Ford (1925, pp. 545-7) predicted that the dense bed in Bigbury Bay would soon become relatively barren owing to lack of replacement stock. The writer has been unable to locate any dense beds of Abra during the last few years.

The figures for Cultellus show a decline from I88. I to 50.0. Sieving losses have already been shown not to be as high as might be imagined, and it seems fairly certain that a decline in population density, of the order of $75 \%$, had occurred. The apparent decline in the population of Nucula turgida may be due to sieving losses in the I950 survey (see above).

The differences in numbers of other species shown in Table XXIV cannot be considered significant, although they may indicate trends which can be confirmed at a later date. The totals for all species except Cultellus and 


\section{Table XXIV. Comparison OF Lamellibranch FaUnas in I922-23 AND I950. NUMBERS PER IO M. ${ }^{2}$}

(The identity of the Lutraria taken in 1950 is uncertain. Some other doubtful identifications are included in the 1950 results, e.g. small specimens of ? Cardium echinatum)

Nucula nucleus

Nucula hanleyi

Nucula turgida

Glycimeris glycimeris

Modiolus phaseolinus

Musculus marmoratus

Chlamys opercularis.

Lima loscombi

Thyasira flexuosa

Myrtea spinifera

Phacoides borealis

Diplodonta rotundata

Lepton squamosum

Montacuta ferruginosa

Mysella bidentata

Cyprina islandica

Cardium echinatum

Cardium ovale

Cardium scabrum

Cardium crassum

Dosinia lupinus.

Gafrarium minimum

Callista chione

Venus casina

Venus ovata

Venus fasciata

Venus striatula

Venerupis rhomboides

Mysia undata

Donax vittatus

Tellina pygmaea

Tellina fabula

Tellina donacina

Tellina crassa

Abra alba

Abra nitida

Abra prismatica

Gari fervensis

Gari tellinella

Solecurtus scopula

Solecurtus chamasolen

Cultellus pellucidus

Ensis ensis

Ensis arcuatus

Mactra corallina

Spisula elliptica

Spisula subtruncata

Lutraria lutraria

Corbula gibba

Thracia villosiuscula

Thracia convexa

Total

\begin{tabular}{|c|c|}
\hline I922-23 & I950 \\
\hline $23 \cdot 2$ & II 4 \\
\hline $\begin{array}{r}1.9 \\
56 \cdot 6\end{array}$ & $\underset{\mathrm{II}}{\ddot{4} 4}$ \\
\hline I3.9. & . \\
\hline$\cdots$ & $I \cdot 4$ \\
\hline$I \cdot 2$ & .. \\
\hline $\begin{array}{l}0.3 \\
0.8\end{array}$ & $\begin{array}{l}4.3 \\
\ldots\end{array}$ \\
\hline $4 \cdot 2$ & $\ddot{\mathrm{II}} \cdot 4$ \\
\hline $4 \cdot 2$ & $\ldots$ \\
\hline$\cdots$ & II 4 \\
\hline $\mathrm{I} \cdot 2$ & $\cdots$ \\
\hline . & $2 \cdot 8$ \\
\hline 0.3 & $\mathrm{I} \cdot 4$ \\
\hline$I \cdot 2$ & $\cdots$ \\
\hline $\mathrm{I} \cdot 2$ & I. 4 \\
\hline $14 \cdot 8$ & $8 \cdot 6$ \\
\hline 0.5 & . \\
\hline 0.4 & I. 4 \\
\hline 0.5 & $\cdots$ \\
\hline $\begin{array}{r}4.9 \\
\text { II. } 8\end{array}$ & I $7 \cdot$ I \\
\hline $\begin{array}{r}\text { II. } 8 \\
0.8\end{array}$ & $\because$ \\
\hline $\begin{array}{l}0.8 \\
\mathrm{I} \cdot 2\end{array}$ & $\begin{array}{l}\cdots \\
\cdots\end{array}$ \\
\hline 14.6 & $\ddot{4} \cdot 3$ \\
\hline 16.8 & I. 4 \\
\hline $\mathrm{I} 2 \cdot \mathrm{I}$ & I. 4 \\
\hline $6 \cdot 7$ & $I \cdot 4$ \\
\hline . & $I \cdot 4$ \\
\hline $2 \cdot 2$ & $\cdots$ \\
\hline $2 \cdot 6$ & $\cdots$ \\
\hline . & $7 \cdot \mathrm{I}$ \\
\hline$\ddot{2} \cdot 8$ & $\begin{array}{l}\text { I. } 4 \\
8.6\end{array}$ \\
\hline $107 \cdot 8$ & $7 \cdot I$ \\
\hline 0.7 & . \\
\hline $37 \cdot 8$ & $2 \cdot 8$ \\
\hline$I \cdot 2$ & $\because$ \\
\hline $4 \cdot 8$ & $\mathrm{I} \cdot 4$ \\
\hline 0.2 & I. 4 \\
\hline $\mathrm{I} \cdot 5$ & $25 \cdot 7$ \\
\hline $\mathrm{I} 88 \cdot \mathrm{I}$ & $50 \cdot 0$ \\
\hline $5 \cdot 5$ & $2 \cdot 8$ \\
\hline . & I. 4 \\
\hline $3 \cdot 7$ & I. 4 \\
\hline $5 \cdot 7$ & . \\
\hline 0.5 & $\cdots$ \\
\hline 9.9 & $\mathrm{I} \cdot 4$ \\
\hline $\begin{array}{r}15 \cdot 2 \\
0.4\end{array}$ & $\because$ \\
\hline $\begin{array}{l}0.4 \\
0.2\end{array}$ & 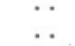 \\
\hline $576 \cdot I$ & $206 \cdot 4$ \\
\hline
\end{tabular}


Abra alba are 280 for I922-23 and I49 for I950. The decline in population numbers appears therefore to be of the order of $50 \%$.

Figures for the brittle-star Ophiothrix fragilis show an increase in numbers over the period. The species usually occurs in dense and localized beds (Vevers, I95I) that this difference may well be fortuitous. Most of the Ophiothrix obtained in 1950 were in one or two individual hauls at $\mathrm{A}_{5}$ and $\mathrm{C}_{3}$.

The population of the heart-urchin Echinocardium cordatum was I5O in I922-23 and I8 in I950. This species must quickly reach a size which does not pass the sieves, so that the decline in numbers is probably greater than the figures would indicate. Many young individuals were taken in the earlier survey.

While there can be little doubt that there has been a decline in the numbers of certain invertebrates, it is not possible to indicate what changes have occurred in the biomass, since no information is available on the exact sizes of individuals taken in Ford's survey.

\section{Mare's survey}

Mare (1942) gives a figure of $75 \mathrm{~g} . / \mathrm{m}^{2}$ fresh weight for the larger macrobenthos in the Rame mud in I939. At A2, a mile or two to the south, there was c. $50 \mathrm{~g} . / \mathrm{m}^{2}$ in 1950 , and the average for all 1950 stations was c. $55 \mathrm{~g}$. (p. 37). It is possible that there had been a slight decline since I939, but the differences might also be due to sampling errors.

\section{DISCUSSION}

The biomass figures given in this paper are a measure of the standing-crop of the macrofauna on the sea-bed off Plymouth during I950. They are intended to provide basic data for following changes in the bottom-fauna in the future.

Before any attempt can be made to correlate the density of the fauna with long-term hydrographic or other changes it will be necessary to know the extent to which the populations fluctuate under constant conditions. Few data, apart from that given by Ford (I925) for some lamellibranchs are available for the Plymouth area.

It is well known that marine populations fluctuate from time to time. Petęrsen (I9I8), for example, gives figures showing changes in the bottomfauna of two Danish fjords over a number of years. While seasonal changes do occur, particularly in shallow water, these are far outweighed by the year to year changes.

Ursin (1952) records considerable changes in the fauna of the Dogger Bank since the survey by Davis (I923). Between 1922 and I95I numbers of Spisula subtruncata and Mactra corallina showed a marked decline, while other species had increased in numbers. Birkett (I953), however, considers that these changes may be partly due to seasonal variations in populations and to differences in sampling gear. 
Major fluctuations appear to be due to the success or otherwise of spat-fall in each year. It follows that these fluctuations are mainly influenced by the suitability of conditions for the growth and development of pelagic larvae. Thorson (I950) considers that survival during larval life is affected mainly by the availability of suitable food and also by the effects of predators. Species with a long larval life tended to show greater fluctuations in their adult populations than species with a shorter larval life. This is due to the greater risks resulting from a long pelagic life which might in some years result in scarcely any larvae reaching the settling stage. Thorson (I950, p. II) states that over $70 \%$ of marine invertebrates have pelagic larvae with a relatively long larval life. He believes that the mortality at the settlement stage is not as great as might be thought since it is now known that many species can postpone settlement until they drift over a suitable substratum (Wilson, I952).

Many instances could be quoted where population fluctuations appear to be associated with good and bad settlement years. Among these are Ford (I925) and Stephen (I93I, I932) for lamellibranch populations.

Great variations may occur in the density of species where soils of varying grade occur within the same area. In the stations worked in 1950 the dry weight ranged from $2 \cdot 6 \mathrm{~g}$. (St. C I) to $2 \mathrm{I} \cdot 4 \mathrm{~g}$. (St. B 7) $/ \mathrm{m}^{2}{ }^{2}$. Jones (I95 I, p. I39) records even greater variations of weight off the Isle of Man. The biomass is not necessarily related to the quantity of organic matter in a deposit, but seems rather to be related to the suitability of the deposit as a habitat for particular species. For example shell-gravel of a particular grade, as at A 5, is favourable for the development of a rich fauna of lamellibranchs and Amphioxus, but if the shell gravel is of a slightly different grade it no longer provides a suitable habitat and is relatively barren.

Davis (I923) and Orton (I937) have emphasized the importance of currents and eddies respectively in the dispersal and settlement of larvae. These may result in the patchy settlement of larvae over a relatively uniform deposit.

The fact that very high population densities are found in certain localized areas suggests that the space requirements of individuals do not normally limit density. Thus Davis (1923) records up to 8250 small Spisula subtruncata $/ \mathrm{m}^{2}$ on the Dogger Bank, and Stephen (I928) records populations of Tellina tenuis on the shore of up to $7588 / \mathrm{m}^{2}$.

Although benthic populations vary greatly in time and place, their density within an area must clearly bear some relation to the fertility of the overlying water mass. The food of most species during pelagic larval life and of suspension feeders in the adult population is the plankton, and since fluctuations in phyto- and zoo-plankton are closely linked with the supply of nutrient salts, it follows that the density of benthic species must similarly be affected.

Raymont (1947, I949, I950) has shown that the addition of fertilizers to an enclosed sea-loch and to an arm of an open sea-loch resulted in a marked increase in the overall density of the bottom fauna. In open sea areas no com- 
parable data are available, but it should be appreciated that changes in the fertility of the water do not necessarily affect all species in the same way. Thus an increase in fertility results not only in a greater supply of food for both larvae and adults but also in an increase in the number of predators. Raymont's results suggest, however, that an increase in bottom population will result in spite of the larger number of predators.

At Plymouth there has been a decline in the fertility of the area since about I93I, associated with the replacement of water characterized by Sagitta elegans by water characterized by $S$. setosa. This decline is measurable in terms of diminished phosphate and other nutrients in the water and by a decline in the number of young fish and of other organisms in the plankton. (The changes are summarized in Kemp, 1938, and Russell, 1939). The Plymouth herring fishery has died out, and Cooper (1948) has shown a decline in landings of the spur-dog (Squalus acanthias) associated with the fall in phosphate content of the water. In the present paper evidence has been given (pp. 39-43) of a probable decline in the numbers of lamellibranchs on the sea-bed since $1922-23$.

Wilson (I95I) has recently shown that other factors besides a decrease in the nutrient salt content of the water may be responsible for a decline in the density of the fauna. He has shown that water from off Plymouth is less favourable for the development of the larvae of certain benthic invertebrates compared with water taken to the westward in the Celtic Sea, which is characterized by Sagitta elegans.

It is natural that changes in the bottom-fauna should take place more slowly than in the plankton owing to the much longer generation time of the larger benthic invertebrates. Raymont (1947, 1949, 1950) found a delay of 2 or 3 years after the commencement of fertilization before anything like a maximal development of bottom fauna was obtained, and a similar lag of a year or so in the decline of the population after addition of fertilisers had ceased.

Many benthic species, particularly lamellibranchs, are believed to have a life span of many years, and the effects of a decline in fertility of the water might only become fully operative after a number of years when the adult spawning stock began to decline in numbers. Young of the lamellibranch Cyprina islandica appeared to be rare or absent in 1950 on grounds where the adult was quite common. While it is true that for a long-lived species the annual rate of replacement need only be small, is it possible that the I950 population of adult Cyprina was spatted under more favourable conditions 20 years or more previously?

Apart from changes in the nature of the water masses, there is some evidence of a northward spread of warmer water species due to a small increase in temperature over the last half century. Spooner (1950) records certain species of amphipod which appear to have spread northward into the Plymouth area in recent years. 
The uniformity of the fauna of the sandy grounds outside the Eddystone suggests that this would be the most favourable area for the study of longterm fluctuations in the benthic population. The fauna can be sampled more accurately than on the patchy grounds inside the Eddystone. The large number of species on this ground, none of which occurs in any great abundance, should tend to lessen year to year changes in the overall population density due to fluctuations in spatfall of individual species.

The only dense beds of invertebrates in the area seem to be the Ophiothrix beds recorded by Vevers (I95I), so it seems unlikely that pelagic larvae of other invertebrates occur in dense aggregations and so give rise to localized spat falls, as on the Dogger Bank (Davis, I923). The absence of eddy currents on offshore grounds should minimize the chance of local settlements associated with swirls as suggested by Orton (1937). In this connexion it is interesting to note that dense beds of Mollusca found off the Devon coast have all been in inshore areas where eddy currents may occur-these are the Abra alba bed in Bigbury Bay (Ford, I923, I925), the Spisula solida bed in Start Bay (Ford, I925; Holme, I950a) and the Turritella communis bed in Teignmouth Bay (Holme, I950a).

\section{SUMMARY}

A survey has been made of the biomass of the macrobenthos at twenty stations in the English Channel off Plymouth. The object was to provide a basis for following long-term fluctuations in the fauna.

A brief survey of physical conditions in the area is given, and a gradeanalysis of the soil at each station has been made.

Core-samples show that the sediment is shallow in many places and rock has been taken at $36 \mathrm{~cm}$. or less below the surface at a number of stations.

Samples totalling $\frac{1}{2} \mathrm{~m}^{2}$ were taken at each station with a modified 'scoopsampler', covering $\frac{1}{10} \mathrm{~m} .{ }^{2}$, which is briefly described.

Sources of error in sampling are considered in detail. Some species may evade the sampler and others live too deep in the sediment to be taken. A comparison against a Petersen grab and a new 'suction-corer' show that the scoop-sampler does take a reasonably quantitative sample.

The number of species taken in successive hauls, when plotted against the $\log$ of the area sampled, approaches a straight-line relationship similar to that obtained by Williams (I950).

A statistical analysis is made of a series of samples taken at one station, and the variance between the two samples in each haul and between successive hauls calculated. At this particular station the fauna in successive samples is shown to be fairly random.

A sieve of $2.2 \mathrm{~mm}$. mesh was employed. Compared with a finer sieve losses in terms of numbers may be quite large, but the total weight taken is little affected. 
The methods used in dry-weight determinations are described in detail.

The fauna and dry weight at each station are listed. On grounds inside the Eddystone both fauna and deposits are patchy, but at nine stations further offshore a fairly constant fauna was taken.

The mean dry weight for all stations is II $2 \mathrm{~g}$. or $c .55 \mathrm{~g}$. fresh weight $/ \mathrm{m} .^{2}$. Much of the total weight is made up of large individuals. $64.4 \%$ is composed of animals weighing more than $0 \cdot 2 \mathrm{~g}$. dry (=c. I.० g. fresh weight).

The composition of the fauna in terms of different groups of animals is given-the greatest weights are Lamellibranchia (35\%), Polychaeta $(26 \%)$ and Echinodermata (18\%).

A brief comparison is made with Allen's (I899) dredge survey. The only change noticed has been in the disappearance of Dentalium entalis from the outside grounds.

A comparison with the grab survey by Ford (I923) seems to indicate an appreciable decline in numbers of lamellibranchs compared with the I922-23 figure. A considerable decline has occurred in populations of Abra alba, Cultellus pellucidus and Echinocardium cordatum.

The biomass figures obtained by Mare (1942) for the Rame mud do not indicate any considerable decline in the fauna between I939 and I950.

Fluctuations in benthic populations are briefly discussed, and it is emphasized that more data are required of seasonal and year to year fluctuations at Plymouth before any changes can be related to the fertility of the watermasses in the area.

The uniformity of the fauna on the outer grounds renders this area suitable for following changes in the bottom fauna.

\section{REFERENCES}

AlleN, E. J., I899. On the fauna and bottom-deposits near the thirty-fathom line from the Eddystone to Start Point. Fourn. Mar. Biol. Assoc., Vol. 5, pp. 365-542.

Armstrond, F. A. J. \& Harvey, H. W., I950. The cycle of phosphorus in the waters of the English Channel. Fourn. Mar. Biol. Assoc., Vol. 29, pp. I45-62.

BIRKETT, L., I953. Change in the composition of the bottom fauna of the Dogger Bank area. Nature, Vol. I7I, p. 265.

Blegvad, H., I925. Continued studies on the quantity of fish food in the sea bottom. Rept. Dan. Biol. Stat., No. 3I, pp. 27-56.

Burdon-Jones, C., I953. Records of British Enteropneusta. Nature, Vol. I7I (in the press).

Chevreux, E. \& Fage, L., I925. Amphipodes. Faune de France, T. 9, 488 pp. Paris.

Cooper, L. H. N., I948. Phosphate and fisheries. Fourn. Mar. Biol. Assoc., Vol. 27, pp. 326-36.

Davis, F. M., I923. Quantitative studies on the fauna of the sea bottom. No. I. Preliminary investigation of the Dogger Bank. Min. Agric. Fish., Fish. Invest., Ser. II, Vol. 6, No. 2, pp. I-54.

- I925. Quantitative studies on the fauna of the sea bottom. No. 2. Results of the investigations in the southern North Sea, I92I-24. Min. Agric. Fish., Fish. Invest., Ser. II, Vol. 8, No. 4, pp. I-50. 
Fauvel, P., 1923. Polychètes errantes. Faune de France, T. 5, 488 pp. Paris.

Forbes, E. \& Hanley, S., I853. A History of British Mollusca and their Shells, Vol. I, 486 pp. London.

ForD, E., I923. Animal communities of the level sea-bottom in the waters adjacent to Plymouth. Fourn. Mar. Biol. Assoc., Vol. 13, pp. I64-224.

ForD, E. 1925. On the growth of some lamellibranchs in relation to the food supply of fishes. Fourn. Mar. Biol. Assoc., Vol. 13, pp. 53I-59.

ForsteR, G. R., I953. A new dredge for collecting burrowing animals. fourn. Mar. Biol. Assoc., Vol. 32, pp. 193-8.

HARVEY, H. W., I950. On the production of living matter in the sea off Plymouth. Fourn. Mar. Biol. Assoc., Vol. 29, pp. 97-I37.

Holme, N. A., 1949. A new bottom-sampler. Fourn. Mar. Biol. Assoc., Vol. 28, pp. 323-32.

— I950 $a$. The bottom-fauna of Great West Bay. Fourn. Mar. Biol. Assoc., Vol. 29, pp. $163-83$.

— I950 b. Population-dispersion in Tellina temuis da Costa. Fourn. Mar. Biol. Assoc., Vol. 29, pp. 267-80.

Johansen, A. C., 1927. Preliminary experiments with Knudsen's bottom sampler for hard bottom. Medd. Komm. Danmarks Havundersøg., København, Ser. Fisk., Bd. 8, No. 4, pp. I-6.

Jones, N. S., I95I. The bottom fauna off the south of the Isle of Man. Fourn. Anim. Ecol., Vol. 20, pp. 132-44.

- 1952. The bottom fauna and the food of flatfish off the Cumberland coast. fourn. Anim. Ecol., Vol. 21, pp. 182-205.

KEMP, S., 1938. Oceanography and the fluctuations in the abundance of marine animals. Presidential Address, Sect. D., Brit. Assoc. Rep., pp. 85-Ior.

KING, W. B. R., I950. Floor of the English Channel. Geol. Mag., Vol. 87, pp. 383-4.

Knudsen, M., 1927. A bottom sampler for hard bottom. Medd. Komm. Danmarks Havundersøg., København, Ser. Fisk., Bd. 8, No. 3, pp. 3-4.

KoeHLeR, R., I886. Contributions à l'étude des Entéropneustes. Recherches anatomiques sur le Balanoglossus sarniensis (nov. sp.). Internat. Monatsschr. Anat. Hist., Bd. 3, pp. I-52.

MARE, M. F., I942. A study of a marine benthic community with special reference to the micro-organisms. Fourn. Mar. Biol. Assoc., Vol. 25, pp. 5I7-54.

Marine Biological Association, 1931. Plymouth Marine Fauna (2nd edition).

MOLANDER, A. R., I928. Investigations into the vertical distribution of the fauna of the bottom deposits in the Gullmar fjord. Svenska Hydrog.-Biol. Komm. Skrifter, Ser. Hydrografi 6, No. 6, pp. I-5.

ORTON, J. H., I937. Some interrelations between bivalve spatfalls, hydrography and fisheries. Nature, Vol. I40, pp. 505-6.

Petersen, C. G. J., I918. The sea bottom and its production of fish-food. Rept. Dan. Biol. Stat., No. 25, pp. I-62.

Petersen, C. G. J. \& Boysen Jensen, P., igi i. Valuation of the sea. I. Animal life of the sea-bottom, its food and quantity. Rept. Dan. Biol. Stat., No. 20, pp. $\mathrm{I}-76$.

RAymont, J. E. G., I947. An experiment in marine fish cultivation. IV. The bottom fauna and the food of flatfishes in a fertilized sea-loch (Loch Craiglin). Proc. Roy. Soc. Edinb., B. Vol. 63, pp. 34-55.

- I949. Further observations on changes in the bottom fauna of a fertilized sea loch. Fourn. Mar. Biol. Assoc., Vol. 28, pp. 9-r9.

- I950. A fish cultivation experiment in an arm of a sea-loch. IV. The bottom fauna of Kyle Scotnish. Proc. Roy. Soc. Edinb., B, Vol. 64, pp. 65-108. 
RusSell, F. S., I939. Hydrographical and biological conditions in the North Sea as indicated by plankton organisms. Fourn. Cons. Int. Explor. Mer., Vol. I4, pp. I7I-92.

SMITH, J. E., I932. The shell gravel deposits, and the infauna of the Eddystone grounds. Fourn. Mar. Biol. Assoc., Vol. 18, pp. 243-78.

Spooner, G. M., I950. Notes on the Plymouth marine fauna: Amphipoda. Fourn. Mar. Biol. Assoc., Vol. 29, pp. 247-53.

Stephen, A. C., I923. Preliminary survey of the Scottish waters of the North Sea by the Petersen grab. Fish., Scotland, Sci. Invest., I922, No. 3, pp. I-2I.

- 1928. Notes on the biology of Tellina tenuis da Costa. Fourn. Mar. Biol. Assoc., Vol. 15, pp. 683-702.

- I93I. Notes on the biology of certain lamellibranchs on the Scottish coast. fourn. Mar. Biol. Assoc., Vol. 17, pp. 277-300.

- I932. Notes on the biology of some lamellibranchs in the Clyde area. Fourn. Mar. Biol. Assoc., Vol. I8, pp. 5I-68.

Steven, G. A., 1930. Bottom fauna and the food of fishes. Fourn. Mar. Biol. Assoc., Vol. I6, pp. 677-705.

Thorson, G., I950. Reproductive and larval ecology of marine bottom invertebrates. Biol. Rev., Vol. 25, pp. I-45.

URsin, E., I952. Change in the composition of the bottom fauna of the Dogger Bank area. Nature, Vol. I70, p. 324.

Vevers, H. G., I95 I. Photography of the sea floor. Fourn. Mar. Biol. Assoc., Vol. 30, pp. IOI-II.

WATKIN, E. E., I938. A revision of the amphipod genus Bathyporeia Lindström. fourn. Mar. Biol. Assoc., Vol. 23, pp. 21 I-36.

WILLIAMS, C. B., I950. The application of the logarithmic series to the frequency of occurrence of plant species in quadrats. Fourn. Ecol., Vol. 38, pp. 107-38.

WILson, D. P., I95I. A biological difference between natural sea waters. Fourn. Mar. Biol. Assoc., Vol. 30, pp. I-20.

- 1952. The influence of the nature of the substratum on the metamorphosis of the larvae of marine animals, especially the larvae of Ophelia bicornis Savigny. Ann. Inst. Oceanogr., T. 27, pp. 49-156.

WInckworth, R., 1932. The British marine Mollusca. Fourn. Conch., Vol. I9, pp. 2 II-52. 